\title{
Pyroxenite dykes with petrological and geochemical affinities to the Alaskan-type ultramafics at the northwestern margin of the Cuddapah basin, Dharwar craton, southern India: Tectonomagmatic implications
}

\author{
Rohit Kumar Giri ${ }^{1}$, Praveer Pankaj ${ }^{1}$, Dinesh Pandit ${ }^{1}$, Samarendra Sahoo ${ }^{1}$, \\ Ramananda Chakrabarti ${ }^{2}$ and N V Chalapathi RaO ${ }^{1, *}$ \\ ${ }^{1}$ Mantle Petrology Laboratory, Department of Geology, Centre of Advanced Study, Institute of Science, Banaras \\ Hindu University, Varanasi 221 005, India. \\ ${ }^{2}$ Centre for Earth Sciences, Indian Institute of Science, Bengaluru 560 012, India. \\ *Corresponding author.e-mail: nvcrao@bhu.ac.in
}

MS received 17 October 2018; revised 2 December 2018; accepted 6 December 2018; published online 8 May 2019

Two previously reported lamprophyre dykes from the Kalwakurthy area, at the northwestern margin of the Cuddapah basin, Dharwar craton, southern India, are reinvestigated. Petrography reveals that they have an overall cumulate texture and comprise clinopyroxene (dominant phase), amphibole (mostly secondary), magnetite, ilmenite and chromite and are reclassified as clinopyroxenites. The chemistry of clinopyroxene and chromite, bulk-rock major and trace element composition and the $\mathrm{Sr}-\mathrm{Nd}$ isotopic systematics of the Kalwakurthy dykes strongly favour the involvement of subduction-related processes in their genesis and are strikingly similar to those of the continental arc-cumulates and Alaskantype ultramafics reported from the supra-subduction type of tectonic settings. Incompatible trace element ratios, involving high field strength elements, of these clinopyroxenites are also suggestive of the fluid-related metasomatism influencing their source regions. Petrogenetic modelling reveals that 10-20\% partial melting of the fertile lithospheric mantle source was involved in their genesis. The tectonomagmatic significance of the studied clinopyroxenites is evaluated in light of the existing models invoking a Neoarchaean subduction in the evolution of the Dharwar craton.

Keywords. Pyroxenite; petrology; geochemistry; Alaskan-type ultramafics; Dharwar craton; southern India.

\section{Introduction}

Pyroxenites are coarse-grained ultramafic igneous rocks known to possess the cumulate texture and dominated by pyroxenes with accessory phases such as olivine, feldspar, chromite, rutile and magnetite-ilmenite pairs. The mineralogical and geochemical diversity of pyroxenites provides insight into the petrological processes contribut- ing to the evolution of the lithospheric mantle (see Downes 2007). Pyroxenites also occur as mantlederived xenoliths in a variety of alkaline magmas and serve as a window to understand the nature of the subcontinental lithospheric mantle (SCLM) (e.g., Karmalkar et al. 2009; Aulbach and Jacob 2016). Pyroxenites are generated by a variety of processes that include: (i) in-situ partial melting, (ii) metamorphic segregation of peridotites, (iii) 
metamorphosed product of the recycled oceanic lithosphere and (iv) high-pressure crystal cumulates from the migrating mantle magma (see Dick and Sinton 1979; Allégre and Turcotte 1986; Bodinier et al. 1987; Sobolev 2007; Tilhac et al. 2017).

Alaskan-type ultramafic rocks were first recorded from southeastern Alaska (Taylor 1967) and subsequently many such rock types/complexes have been reported from convergent margins ( $\mathrm{Su}$ et al. 2012; Yuan et al. 2017). Alaskan-type ultramafic rocks are known to span from the Neoarchaean to the Cenozoic era (e.g., Taylor 1967; Cai et al. 2012; Sappin et al. 2012; Helmy et al. 2014; Tessalina et al. 2016) and are intimately associated with convergent plate margins and hence are of unique geodynamic significance (e.g., Su et al. 2014; Yuan et al. 2017). A dominance of clinopyroxene coupled with the paucity of orthopyroxene and plagioclase together with the enrichment in light rare earth element (LREE) and the concomitant depletion in high field strength element (HFSE) in the present study are well-known characteristic features of the Alaskan-type ultramafics (Himmelberg and Loney 1995; Pettigrew and Hattori 2006; Eyuboglu et al. 2010; Helmy et al. 2014; Su et al. 2014).

From the Indian shield, pyroxenites have been reported from various cratons and mobile belts (e.g., Rao and Raman 1979; Kutty et al. 1986; Natarajan et al. 1994; Le Bas et al. 2002; Srivastava and Sinha 2007; Samuel et al. 2018). Some of the well-studied Indian occurrences of pyroxenites include (i) Jasra complex, Shillong plateau (Srivastava and Sinha 2007); (ii) Kondapalle-layered complex (Dharma Rao and Santosh 2011 and references therein) and the Chimakurti gabbroanorthosite-ultramafic complex at the eastern margin of the Cuddapah basin (Rao et al. 1988) in the Dharwar craton; (iii) Puttetti complex, Trivandrum block (Rajesh 2003) and (iv) Borra complex, Eastern Ghats (Le Bas et al. 2002). In this paper, we reinterpret the recently reported 'Kalwakurthy lamprophyre' (from the Polkampalli and Potepalli areas) dykes (Meshram and Venkateswara Rao 2009) from the northwestern margin of the Cuddapah basin in the Dharwar craton, southern India, as pyroxenites. We demonstrate, based on the petrography, mineral chemistry and bulk-rock geochemistry (including $\mathrm{Sr}$ and $\mathrm{Nd}$ isotopes) that these dykes have characteristics of continental arc-related clinopyroxenites. We also propose their petrogenetic model and explore the tectonomagmatic significance of these dykes.

\section{Geological background}

The Dharwar craton of southern India is a classical granite-greenstone terrain and is traditionally divided into the western Dharwar craton and eastern Dharwar craton (Naqvi and Rogers 1987; Ramakrishnan and Vaidyanadhan 2008). However, recent studies favour the Dharwar craton to be a composite mosaic of micro-blocks (Peucat et al. 2013; Jayananda et al. 2018; figure 1a). Three such blocks - western, central and eastern - are recognised based on multiple criteria such as the (i) abundance of greenstone belts, (ii) thickness of the crust, (iii) metamorphism and (iv) melting of the basement (see Jayananda et al. 2018 and references therein). Based on published geochronological data there are five major periods of crust formation in the Dharwar craton at ca. 3450-3300, 3230-3150, 3000-2960, 2700-2600 and 2560-2520 Ma, which are subcontemporaneous with greenstone volcanism (Jayananda et al. 2018). A NNW-SSE trending shear zone along the eastern margin of the Chitradurga greenstone belt is considered to separate the western block from the central block. On the other hand, the Chitradurga shear zone and the western margin of the Kolar-Kadiri schist belt comprise the western and eastern limits, respectively, of the central block. The eastern block extends beyond the Kolar-Kadiri belt (Jayananda et al. 2018).

The western block is dominated by the tonalitetrondhjemite-granodiorite (TTG) gneisses, two generations of greenstone sequences and high potassic granites. The central block comprises abundant granitoids, including the N-S trending 500-km long Closepet granite, banded tonalitic to granodioritic gneisses, migmatitic TTG and greenstone belts. The lithology of the eastern block includes several calc-alkaline intrusions (collectively termed the Dharwar batholith), banded gneisses and greenstone belts containing lesser volcanics (Swami Nath et al. 1976; Radhakrishna and Naqvi 1986; Chadwick et al. 2000; Ramakrishnan and Vaidyanadhan 2008; Jayananda et al. 2018). These volcanics are associated with the convergent margins and comprise basalts, boninites, tholeiitic to calcalkaline basalts, Mg-andesites and adakites. Relatively younger Palaeo-to-Mesoproterozoic platform type Purana sedimentary sequences in the Cuddapah, Kaladgi and Bhima basins are also present within the Dharwar craton. Several Mesoproterozoic kimberlites (1.1 Ga) and lamproites (1.4$1.25 \mathrm{Ga})$ are also documented from the Dharwar 

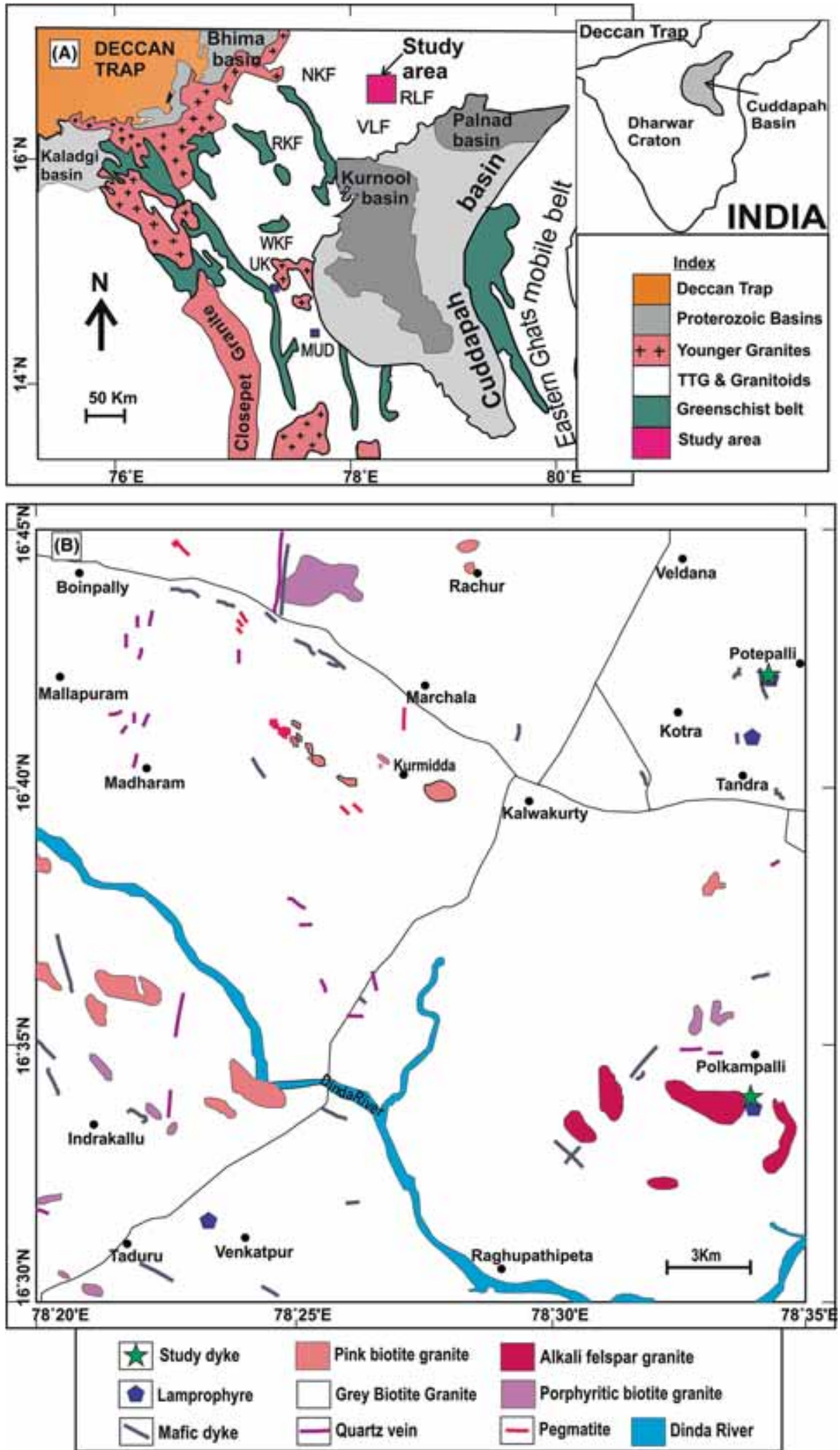

Figure 1. (a) A generalised geological map showing a part of the eastern Dharwar craton, Cuddapah basin and its surrounding areas showing the location of the study area along with the disposition of various alkaline and subalkaline rocks (after Naqvi 2005). (b) A generalised geological map of the study area around Kalwakurthy town showing the location of pyroxenite bodies (after Meshram and Venkateswara Rao 2009). Abbreviations: MUD, Mudigubba lamprophyre; UK, Udiripikonda lamprophyre; WKF, Wajrakarur kimberlite field; NKF, Narayanpet kimberlite field; RKF, Raichur kimberlite field; VLF, Vattikod lamproite field; RLF, Ramadugu lamproite field. 


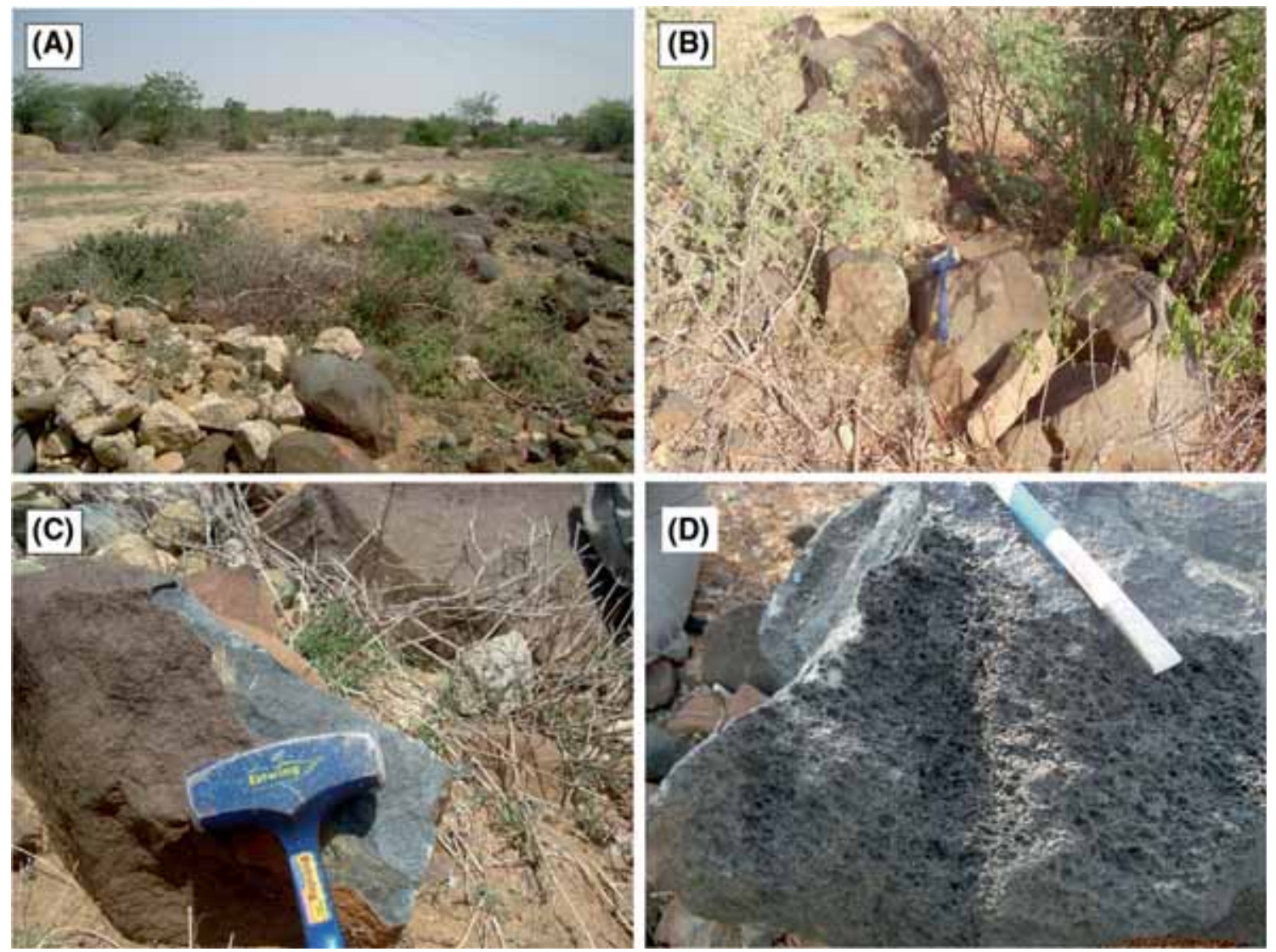

Figure 2. Field photographs of Kalwakurthy pyroxenites. (a) Polkampalli dyke, (b) Potepalli dyke, (c) close view of Polkampalli dyke showing brown coloured weathered surface and shining fresh surface, (d) pits in the Potepalli dyke.

craton (Chalapathi Rao et al. 2013, 2014). The end-Cretaceous Deccan trap lavas and black soil and alluvium of the recent age constitute the youngest geological units.

The pyroxenites of this study occur as dykes and are located $2 \mathrm{~km}$ south of Polkampalli $\left(16^{\circ} 34^{\prime} 05.4^{\prime \prime} \mathrm{N} ; 78^{\circ} 33^{\prime} 46.2^{\prime \prime} \mathrm{E}\right)$, and $2 \mathrm{~km}$ WSW of Potepalli $\left(16^{\circ} 42^{\prime} 11.7^{\prime \prime} \mathrm{N} ; 78^{\circ} 34^{\prime} 15.4^{\prime \prime} \mathrm{E}\right)$ villages near the Kalwakurthy area (figure 1b). As previously mentioned, these dykes were reported by the Geological Survey of India a decade ago and identified as 'lamprophyres' (see Meshram and Venkateswara Rao 2009). The Polkampalli pyroxenite has a width of $5 \mathrm{~m}$ and a length of $50 \mathrm{~m}$ and strikes $\mathrm{N}-\mathrm{S}$ to $\mathrm{N} 10^{\circ} \mathrm{W}-\mathrm{S} 10^{\circ} \mathrm{E}$ (figure $2 \mathrm{a}$ and $\mathrm{b}$ ). The Potepalli pyroxenite trends NW-SE with a width of $20 \mathrm{~m}$ and length of 150-200 m (figure $2 \mathrm{c}$ and $\mathrm{d}$ ). Both these dykes intrude the coarse-grained grey biotite granite of granodioriteadamellite-granite suite of Archaean age (Gopal Reddy et al. 1992). Pyroxenite dykes are darkcoloured and dominated by pyroxenes and their weathered surfaces have a pale brown colour whereas the fresh surface is dark-greenish and meso-melanocratic in appearance (figure 2).

\section{Analytical techniques}

The mineral chemistry of various phases in the studied samples was determined by CAMECA SXFive electron microprobe microanalysis (EPMA) at the department of geology, Banaras Hindu University, Varanasi. Wavelength-dispersive spectrometry and a $\mathrm{LaB}_{6}$ filament have been deployed for quantitative analyses. For X-ray 'dot' mapping, an acceleration voltage of $15 \mathrm{kV}$ and a beam current of $100 \mathrm{nA}$ were used, whereas $15 \mathrm{kV}$ and $10 \mathrm{nA}$ were deployed for BSE imaging. An accelerating voltage of $15 \mathrm{kV}$, a beam current of $10 \mathrm{nA}$ and a beam diameter of $1 \mu \mathrm{m}$ along with TAP, LPET and LLIF crystals were employed for measurement. Several natural and synthetic standards were used for calibration. Based on multiple analyses, it was found that the error on major element concentrations is $<1 \%$, whereas the error on trace 
elements varied between $3 \%$ and $5 \%$. The representative microprobe data are presented in tables 1-4.

Rock chips of the samples were powdered using a Retsch BB50 jaw crusher and Retsch RM100 motor grinder at the department of geology, Banaras Hindu University, and subjected to whole-rock geochemical analysis and isotopic study. The wholerock geochemical analysis was carried out at Activation Laboratories, Ancaster, Canada. Alkaline fusion and ICP-OES analysis (ThermoJarrell-Ash ENVIRO II model) were used to analyse major elements and a few trace elements $(\mathrm{V}$, $\mathrm{Sc}, \mathrm{Sr}, \mathrm{Ba}, \mathrm{Zr}$ and $\mathrm{Y}$ ), and multi-acid digestion and Inductively coupled plasma mass spectrometry (ICP-MS) analysis (Model: Perkin Elmer Sciex ELAN 6000) were used for the measurement of trace and rare earth element (REE) concentrations. STM1 MRG1, DNC1, W2 and SY3 were used as internal standards and the precision is $\sim 5 \%$ and 5-10\% for the major oxides and trace elements, respectively. Bulk-rock major and trace element data are presented in table 5.

Strontium and neodymium isotope ratio measurements of the two samples, one each from the two dykes, were obtained using a Inductively coupled plasma mass spectrometry (ICP-MS) at the Centre for Earth Sciences, Indian Institute of Science following the same protocol as described by Banerjee et al. (2016). The concentrations of Rb, $\mathrm{Sr}, \mathrm{Sm}$ and Nd measured by ICP-MS were used. Samples were digested using ultra-pure acid mixtures of $\mathrm{HF}, \mathrm{HNO}_{3}$ and $\mathrm{HCl}$. Analyses of standards and repeat sample were performed to illustrate the accuracy and precision of both major and trace element analyses. The measured ${ }^{87} \mathrm{Sr} /{ }^{86} \mathrm{Sr}$ and ${ }^{143} \mathrm{Nd} /{ }^{144} \mathrm{Nd}$ ratios were normalised to ${ }^{86} \mathrm{Sr} /{ }^{88} \mathrm{Sr}=$ 0.1194 and ${ }^{146} \mathrm{Nd} /{ }^{144} \mathrm{Nd}=0.7219$, respectively, to correct for instrumental mass fractionation. The JNdi-1 Nd isotopic standard and SRM-987 Sr isotopic standard were analysed along with the samples and yielded values of ${ }^{143} \mathrm{Nd} /{ }^{144} \mathrm{Nd}=$ $0.512120 \pm 7(2 \mathrm{SD}, n=3)$ and ${ }^{87} \mathrm{Sr} /{ }^{86} \mathrm{Sr}=$ $0.710260 \pm 9$ (2SD, $n=3)$, respectively. The results obtained are listed in table 6 .

\section{Petrography and mineral chemistry}

The petrographic study of the Kalwakurthy pyroxenites (from Potepalli and Polkampalli) reveal that they consist of clinopyroxene (dominant phase), amphibole along with interstitial oxides of magnetite-ilmenite and chromite (figure 3a). The oxide phases are present as coarser grains and dusty granules along cleavages of silicate minerals (figure 3b). An overall igneous cumulate texture is present, where amphibole and clinopyroxene are present as cumulates. Amphiboles are of both primary and secondary types, with the secondary amphiboles derived from the clinopyroxenes as evident from their relict cleavage (figure $3 \mathrm{c}-\mathrm{f}$ ). Whereas augite is the sole clinopyroxene in the Potepalli dyke, the Polkampalli dyke also contains a smaller proportion of pigeonite besides augite (figure 4a). Most of the pyroxenes are also altered to chlorite and serpentine; however, pristine clinopyroxene grains are also present. It is well known that a porphyritic-panidiomorphic texture, hydrous mafic silicates as phenocrysts and felsic groundmass are essential attributes of lamprophyres (see Rock 1991) which are lacking in the dykes under study. Olivine pseudomorphs are also noticed at some places. It should be pointed out that chromite is present only in the Polkampalli pyroxenite, whereas the pyroxenite of Potepalli is entirely devoid of it. Chromites, where present, are well-preserved with crystal shapes and euhedral form and display marked zoning (figure $3 \mathrm{~g}$ and $\mathrm{h}$ ).

\subsection{Pyroxene}

The mineral chemistry data of the clinopyroxenes is provided in table 1. Clinopyroxene displays a substantial variation in its composition between the Polkampalli $\left(\mathrm{Wo}_{18.23-27.81} \mathrm{En}_{42.54-59.31}\right.$ $\left.\mathrm{Fs}_{14.66-40.07}\right)$ and the Potepalli $\left(\mathrm{Wo}_{26.09-28.04}\right.$ $\left.\mathrm{En}_{52.59-58.22} \mathrm{Fs}_{15.17-19.83}\right)$ dykes. Clinopyroxenes from both the dykes are rich in calcium (8.98 $12.83 \mathrm{wt} \%)$ but depleted in $\mathrm{Na}_{2} \mathrm{O}(0.18-0.36 \mathrm{wt} \%)$, $\mathrm{Al}_{2} \mathrm{O}_{3}(0.84-3.81 \mathrm{wt} \%)$ and $\mathrm{TiO}_{2}(0.05-0.87 \mathrm{wt} \%)$ (see table 1). A slight enrichment of $\mathrm{Ca}$ together with lower $\mathrm{Al}$, $\mathrm{Ti}$ and $\mathrm{Na}$ contents are similar to those reported from Alaskan-type complexes (Snoke et al. 1981; Helmy and El Mahallawi 2003), whereas high $\mathrm{MgO}$ (15.79-19.79 wt\%), high $\mathrm{Mg} \#$ (57-74) and variable alumina and $\mathrm{TiO}_{2}$ are similar to arc-related cumulates (Yuan et al. 2017). In the Ca (a.p.f.u.) vs. Ti (a.p.f.u.) space (figure 4b), clinopyroxenes from the Pokampalli dyke display a strong orogenic character, whereas those from the Potepalli dyke portray a mixed orogenic to non-orogenic nature. $\mathrm{TiO}_{2}$ vs. $\mathrm{Al}_{z}$ in the clinopyroxene plot further confirms their arc cumulate type nature (figure $4 \mathrm{c}$ ). 


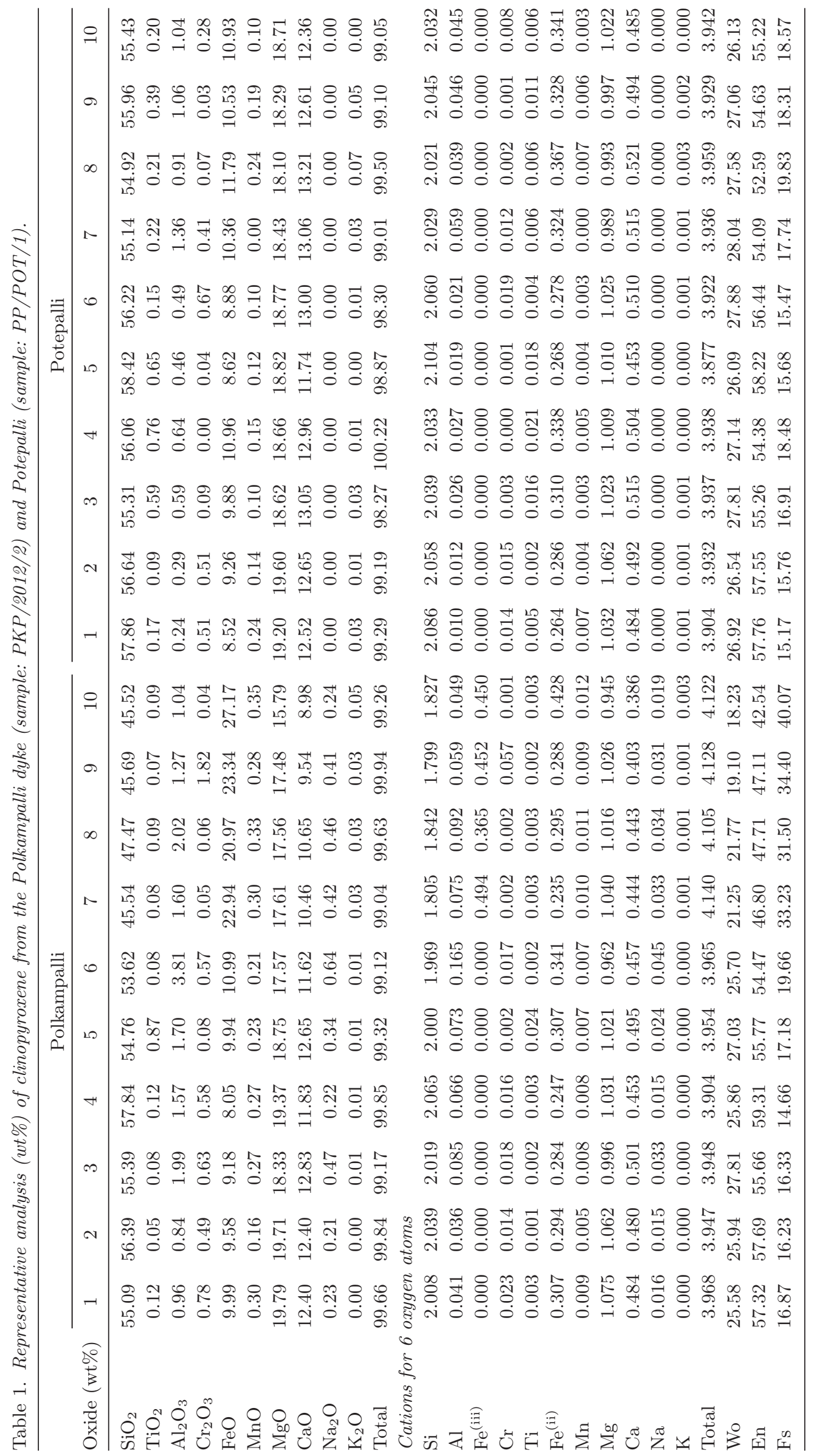




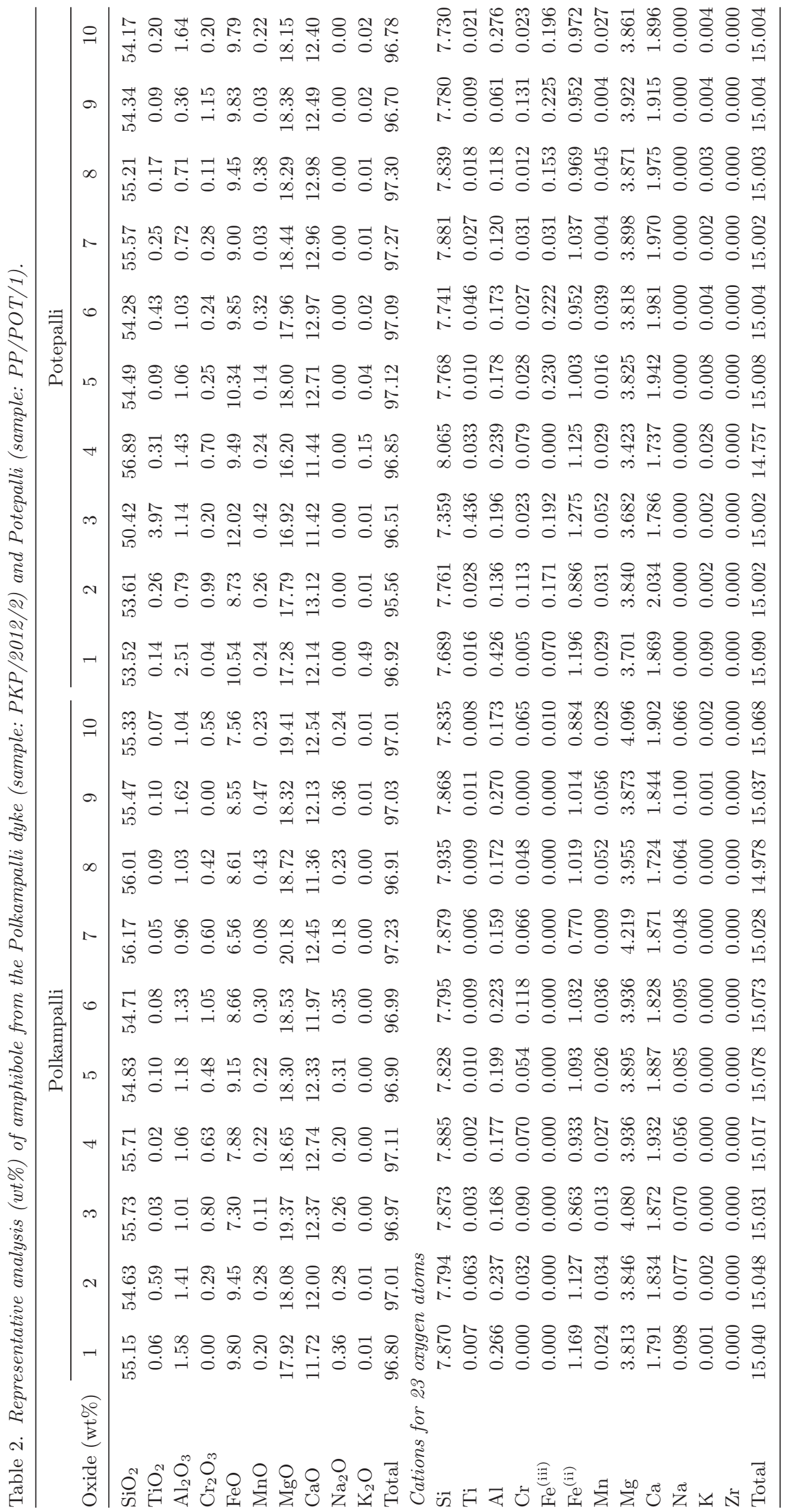




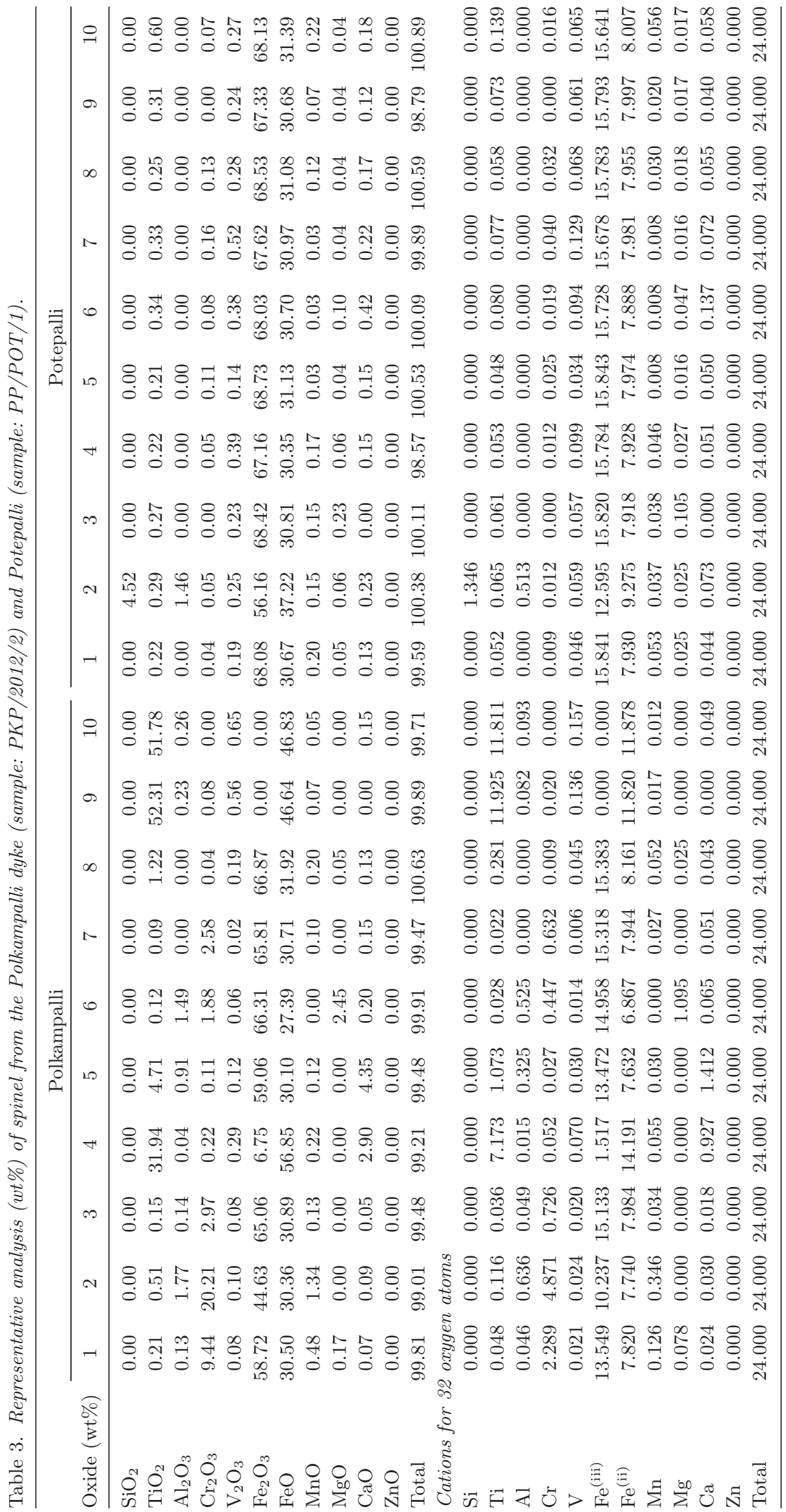


Table 4. Representative analysis (wt\%) chromite from the Polkampalli dyke (sample: PKP/2012/2).

\begin{tabular}{|c|c|c|c|c|c|c|c|c|c|c|}
\hline Oxide (wt\%) & 1 & 2 & 3 & 4 & 5 & 6 & 7 & 8 & 9 & 10 \\
\hline $\mathrm{SiO}_{2}$ & 0.00 & 0.00 & 0.00 & 0.00 & 0.00 & 0.00 & 0.00 & 0.00 & 0.13 & 0.06 \\
\hline $\mathrm{TiO}_{2}$ & 0.66 & 0.87 & 0.82 & 0.84 & 0.91 & 0.62 & 0.89 & 0.86 & 0.50 & 0.66 \\
\hline $\mathrm{Al}_{2} \mathrm{O}_{3}$ & 4.84 & 5.06 & 4.93 & 5.12 & 4.36 & 4.77 & 4.76 & 4.85 & 4.76 & 5.23 \\
\hline $\mathrm{Cr}_{2} \mathrm{O}_{3}$ & 53.27 & 53.03 & 53.46 & 53.01 & 53.63 & 53.24 & 52.50 & 52.50 & 52.85 & 53.01 \\
\hline $\mathrm{V}_{2} \mathrm{O}_{3}$ & 0.25 & 0.30 & 0.26 & 0.31 & 0.18 & 0.23 & 0.32 & 0.25 & 0.00 & 0.08 \\
\hline $\mathrm{Fe}_{2} \mathrm{O}_{3}$ & 7.55 & 7.07 & 6.69 & 7.03 & 7.53 & 7.88 & 7.68 & 7.19 & 8.78 & 6.89 \\
\hline $\mathrm{FeO}$ & 31.13 & 31.96 & 31.27 & 30.64 & 31.64 & 31.48 & 30.91 & 30.47 & 30.62 & 31.45 \\
\hline $\mathrm{MnO}$ & 1.98 & 1.53 & 2.06 & 2.75 & 1.80 & 1.80 & 2.34 & 2.62 & 1.47 & 1.49 \\
\hline $\mathrm{MgO}$ & 0.00 & 0.00 & 0.00 & 0.00 & 0.00 & 0.00 & 0.00 & 0.00 & 0.17 & 0.08 \\
\hline $\mathrm{CaO}$ & 0.13 & 0.01 & 0.00 & 0.06 & 0.05 & 0.00 & 0.09 & 0.01 & 0.16 & 0.08 \\
\hline $\mathrm{ZnO}$ & 0.00 & 0.00 & 0.00 & 0.00 & 0.00 & 0.00 & 0.00 & 0.00 & 0.00 & 0.00 \\
\hline Total & 99.82 & 99.83 & 99.50 & 99.75 & 100.10 & 100.03 & 99.49 & 98.75 & 99.45 & 99.02 \\
\hline \multicolumn{11}{|c|}{ Cations for 32 oxygen atoms } \\
\hline $\mathrm{Si}$ & 0.000 & 0.000 & 0.000 & 0.000 & 0.000 & 0.000 & 0.000 & 0.000 & 0.039 & 0.017 \\
\hline $\mathrm{Ti}$ & 0.145 & 0.191 & 0.181 & 0.185 & 0.200 & 0.137 & 0.197 & 0.191 & 0.128 & 0.146 \\
\hline $\mathrm{Al}$ & 1.670 & 1.742 & 1.704 & 1.762 & 1.501 & 1.643 & 1.648 & 1.690 & 1.654 & 1.812 \\
\hline $\mathrm{Cr}$ & 12.319 & 12.252 & 12.396 & 12.248 & 12.400 & 12.296 & 12.185 & 12.269 & 12.320 & 12.320 \\
\hline $\mathrm{V}$ & 0.060 & 0.070 & 0.061 & 0.073 & 0.042 & 0.054 & 0.076 & 0.058 & 0.000 & 0.018 \\
\hline $\mathrm{Fe}^{(\mathrm{iii})}$ & 1.661 & 1.554 & 1.477 & 1.545 & 1.657 & 1.733 & 1.696 & 1.600 & 1.947 & 1.524 \\
\hline $\mathrm{Fe}^{(\mathrm{ii})}$ & 7.614 & 7.809 & 7.669 & 7.487 & 7.738 & 7.691 & 7.589 & 7.531 & 7.549 & 7.731 \\
\hline $\mathrm{Mn}$ & 0.491 & 0.378 & 0.513 & 0.681 & 0.447 & 0.446 & 0.581 & 0.656 & 0.367 & 0.372 \\
\hline $\mathrm{Mg}$ & 0.000 & 0.000 & 0.000 & 0.000 & 0.000 & 0.000 & 0.000 & 0.000 & 0.073 & 0.034 \\
\hline $\mathrm{Ca}$ & 0.040 & 0.004 & 0.000 & 0.017 & 0.016 & 0.000 & 0.028 & 0.004 & 0.051 & 0.026 \\
\hline $\mathrm{Zn}$ & 0.000 & 0.000 & 0.000 & 0.000 & 0.000 & 0.000 & 0.000 & 0.000 & 0.000 & 0.000 \\
\hline
\end{tabular}

Table 5. Whole rock geochemistry data for Kalwakurthy pyroxenites.

\begin{tabular}{|c|c|c|c|c|c|c|c|c|}
\hline \multirow[b]{2}{*}{ Oxide (wt\%) } & \multicolumn{4}{|c|}{ Polkampalli } & \multicolumn{4}{|c|}{ Potepalli } \\
\hline & $\mathrm{PKP} / 2012 / 1$ & $\mathrm{PKP} / 2012 / 2$ & $\mathrm{PP} / \mathrm{POL} / 1$ & $\mathrm{PP} / \mathrm{POL} / 3$ & $\mathrm{PP} / \mathrm{POT} / 1$ & $\mathrm{PP} / \mathrm{POT} / 2$ & PTL/2012/1 & PTL/2012/3 \\
\hline $\mathrm{SiO}_{2}$ & 46.34 & 47.69 & 45.97 & 47.17 & 50.11 & 50.51 & 46.31 & 46.33 \\
\hline $\mathrm{TiO}_{2}$ & 0.99 & 1.05 & 0.89 & 0.85 & 1.12 & 1.11 & 0.85 & 1.40 \\
\hline $\mathrm{Al}_{2} \mathrm{O}_{3}$ & 6.72 & 6.73 & 6.15 & 5.24 & 6.8 & 6.56 & 5.83 & 14.35 \\
\hline $\mathrm{Fe}_{2} \mathrm{O}_{3}$ & 14.25 & 14.37 & 14.39 & 13.63 & 14.05 & 14.2 & 14.57 & 12.83 \\
\hline $\mathrm{MnO}$ & 0.19 & 0.18 & 0.18 & 0.184 & 0.19 & 0.2 & 0.18 & 0.18 \\
\hline $\mathrm{MgO}$ & 18.02 & 16.47 & 18.83 & 19.84 & 14.31 & 14.24 & 19.47 & 8.38 \\
\hline $\mathrm{CaO}$ & 8.63 & 8.53 & 8.07 & 8.56 & 8.54 & 8.8 & 7.25 & 7.67 \\
\hline $\mathrm{Na}_{2} \mathrm{O}$ & 0.37 & 0.96 & 0.25 & 0.26 & 1.57 & 1.67 & 0.2 & 2.91 \\
\hline $\mathrm{K}_{2} \mathrm{O}$ & 0.05 & 0.04 & 0.03 & 0.05 & 0.68 & 0.63 & 0.45 & 1.23 \\
\hline $\mathrm{P}_{2} \mathrm{O}_{5}$ & 0.09 & 0.11 & 0.09 & 0.08 & 0.1 & 0.1 & 0.08 & 0.18 \\
\hline LOI & 4.09 & 3.65 & 4.16 & 3.64 & 1.9 & 2.07 & 3.79 & 3.4 \\
\hline Total & 99.77 & 99.78 & 99.03 & 99.51 & 99.39 & 100.1 & 98.99 & 98.87 \\
\hline $\mathrm{Mg} \#$ & 90.9 & 90.1 & 91.2 & 92 & 89 & 88.8 & 91.4 & 83.8 \\
\hline \multicolumn{9}{|c|}{ Trace elements (ppm) } \\
\hline $\mathrm{Sc}$ & 16 & 19 & 16 & 18 & 21 & 22 & 16 & 20 \\
\hline $\mathrm{V}$ & 148 & 167 & 144 & 143 & 182 & 188 & 141 & 214 \\
\hline $\mathrm{Ba}$ & 36 & 30 & 7 & 7 & 121 & 121 & 38 & 432 \\
\hline $\mathrm{Sr}$ & 54 & 142 & 39 & 60 & 319 & 341 & 62 & 560 \\
\hline $\mathrm{Y}$ & 11 & 13 & 12 & 10 & 14 & 15 & 11 & 13 \\
\hline $\mathrm{Zr}$ & 101 & 97 & 84 & 85 & 110 & 97 & 79 & 104 \\
\hline $\mathrm{Cr}$ & 1110 & 1130 & 1260 & 1300 & 1030 & 1300 & 1250 & 370 \\
\hline Co & 89 & 82 & 96 & 91 & 78 & 77 & 97 & 58 \\
\hline $\mathrm{Ni}$ & 880 & 790 & 1070 & 1010 & 680 & 740 & 1120 & 230 \\
\hline
\end{tabular}


Table 5. (Continued.)

\begin{tabular}{|c|c|c|c|c|c|c|c|c|}
\hline \multirow[b]{2}{*}{ Oxide (wt\%) } & \multicolumn{4}{|c|}{ Polkampalli } & \multicolumn{4}{|c|}{ Potepalli } \\
\hline & $\mathrm{PKP} / 2012 / 1$ & $\mathrm{PKP} / 2012 / 2$ & $\mathrm{PP} / \mathrm{POL} / 1$ & $\mathrm{PP} / \mathrm{POL} / 3$ & $\mathrm{PP} / \mathrm{POT} / 1$ & $\mathrm{PP} / \mathrm{POT} / 2$ & PTL/2012/1 & PTL $/ 2012 / 3$ \\
\hline $\mathrm{Cu}$ & 140 & 240 & 180 & 190 & 300 & 290 & 200 & 20 \\
\hline $\mathrm{Zn}$ & 90 & 90 & 90 & 90 & 100 & 110 & 100 & 240 \\
\hline $\mathrm{Ga}$ & 11 & 11 & 10 & 9 & 11 & 11 & 10 & 17 \\
\hline $\mathrm{Rb}$ & 2 & 2 & 2 & 2 & 50 & 44 & 40 & 44 \\
\hline $\mathrm{Nb}$ & 6 & 6 & 6 & 6 & 6 & 5 & 5 & 10 \\
\hline $\mathrm{La}$ & 15.6 & 15.3 & 12.7 & 13 & 14.4 & 14.2 & 12.2 & 11.7 \\
\hline $\mathrm{Ce}$ & 32.8 & 33.4 & 28 & 27.5 & 30.9 & 31.9 & 26.6 & 27.1 \\
\hline $\operatorname{Pr}$ & 4.08 & 4.15 & 3.52 & 3.48 & 4.14 & 4.06 & 3.33 & 3.69 \\
\hline $\mathrm{Nd}$ & 16.8 & 17.8 & 14.7 & 14.7 & 18 & 17.2 & 13.7 & 16.9 \\
\hline $\mathrm{Sm}$ & 3.9 & 4.1 & 3.2 & 3.5 & 4.7 & 4.3 & 3.2 & 4 \\
\hline $\mathrm{Eu}$ & 1.17 & 1.17 & 1 & 1.1 & 1.31 & 1.27 & 0.86 & 1.26 \\
\hline $\mathrm{Gd}$ & 3.5 & 4 & 3.1 & 3.2 & 3.9 & 4.1 & 3 & 3.5 \\
\hline $\mathrm{Tb}$ & 0.5 & 0.6 & 0.5 & 0.5 & 0.6 & 0.6 & 0.4 & 0.5 \\
\hline Dy & 3.1 & 3.2 & 2.7 & 2.6 & 3.4 & 3.5 & 2.5 & 3.1 \\
\hline Ho & 0.5 & 0.6 & 0.5 & 0.5 & 0.6 & 0.6 & 0.4 & 0.6 \\
\hline Er & 1.5 & 1.7 & 1.4 & 1.4 & 1.8 & 1.8 & 1.3 & 1.6 \\
\hline $\mathrm{Tm}$ & 0.21 & 0.22 & 0.19 & 0.2 & 0.27 & 0.24 & 0.17 & 0.23 \\
\hline $\mathrm{Yb}$ & 1.3 & 1.4 & 1.3 & 1.3 & 1.7 & 1.5 & 1 & 1.3 \\
\hline $\mathrm{Lu}$ & 0.2 & 0.22 & 0.17 & 0.19 & 0.23 & 0.25 & 0.17 & 0.2 \\
\hline Hf & 2.2 & 2.5 & 2.3 & 2 & 2.4 & 2.4 & 1.9 & 2.2 \\
\hline $\mathrm{Ta}$ & 0.5 & 0.5 & 0.5 & 0.4 & 0.6 & 0.6 & 0.4 & 0.7 \\
\hline $\mathrm{Pb}$ & 21 & 49 & 12 & 6 & 18 & 14 & 7 & 82 \\
\hline Th & 3.2 & 3.5 & 3.1 & 2.5 & 3.3 & 3.6 & 2.7 & 1.1 \\
\hline $\mathrm{U}$ & 1.1 & 1.4 & 1.5 & 1.4 & 2 & 2.2 & 1.7 & 0.3 \\
\hline Er & 1.5 & 1.7 & 1.4 & 1.4 & 1.8 & 1.8 & 1.3 & 1.6 \\
\hline $\mathrm{Tm}$ & 0.21 & 0.22 & 0.19 & 0.2 & 0.27 & 0.24 & 0.17 & 0.23 \\
\hline $\mathrm{Yb}$ & 1.3 & 1.4 & 1.3 & 1.3 & 1.7 & 1.5 & 1 & 1.3 \\
\hline $\mathrm{Lu}$ & 0.2 & 0.22 & 0.17 & 0.19 & 0.23 & 0.25 & 0.17 & 0.2 \\
\hline Hf & 2.2 & 2.5 & 2.3 & 2 & 2.4 & 2.4 & 1.9 & 2.2 \\
\hline $\mathrm{Ta}$ & 0.5 & 0.5 & 0.5 & 0.4 & 0.6 & 0.6 & 0.4 & 0.7 \\
\hline $\mathrm{Pb}$ & 21 & 49 & 12 & 6 & 18 & 14 & 7 & 82 \\
\hline Th & 3.2 & 3.5 & 3.1 & 2.5 & 3.3 & 3.6 & 2.7 & 1.1 \\
\hline $\mathrm{U}$ & 1.1 & 1.4 & 1.5 & 1.4 & 2 & 2.2 & 1.7 & 0.3 \\
\hline
\end{tabular}

Table 6. Sm-Nd and Rb-Sr isotopic data of the Kalwakurthy pyroxenites.

\begin{tabular}{|c|c|c|c|c|c|c|c|}
\hline \multicolumn{8}{|c|}{ Sm-Nd compositions } \\
\hline Samples & $\mathrm{Sm}(\mathrm{ppm})$ & $\mathrm{Nd}(\mathrm{ppm})$ & ${ }^{147} \mathrm{Sm} /{ }^{144} \mathrm{Nd}$ & ${ }^{143} \mathrm{Nd} /{ }^{144} \mathrm{Nd}$ & ${ }^{143} \mathrm{Nd} /{ }^{144} \mathrm{Nd}_{\text {initial }}$ & $\varepsilon \mathrm{Nd}_{\text {initial }}$ & $T_{\mathrm{DM}}$ in $\mathrm{Ga}$ \\
\hline $\mathrm{PKP} / 2012 / 1$ & 3.9 & 16.8 & 0.1403 & 0.511661 & 0.509916 & -5.4 & 2.70 \\
\hline$\underline{\mathrm{PP} / \mathrm{POT} / 1}$ & 4.7 & 18 & 0.1578 & 0.511650 & 0.509687 & -9.9 & 3.44 \\
\hline \multicolumn{8}{|c|}{ Rb-Sr compositions } \\
\hline Samples & $\mathrm{Rb}(\mathrm{ppm})$ & $\mathrm{Sr}(\mathrm{ppm})$ & ${ }^{87} \mathrm{Rb} /{ }^{86} \mathrm{Sr}$ & ${ }^{87} \mathrm{Sr} /{ }^{86} \mathrm{Sr}$ & \multicolumn{3}{|c|}{${ }^{87} \mathrm{Sr} /{ }^{86} \mathrm{Sr}_{\text {initial }}$} \\
\hline $\mathrm{PKP} / 2012 / 1$ & 2 & 54 & 0.1073 & 0.714600 & \multicolumn{3}{|c|}{0.711682} \\
\hline $\mathrm{PP} / \mathrm{POT} / 1$ & 50 & 319 & 0.4541 & 0.717738 & \multicolumn{3}{|c|}{0.705386} \\
\hline
\end{tabular}



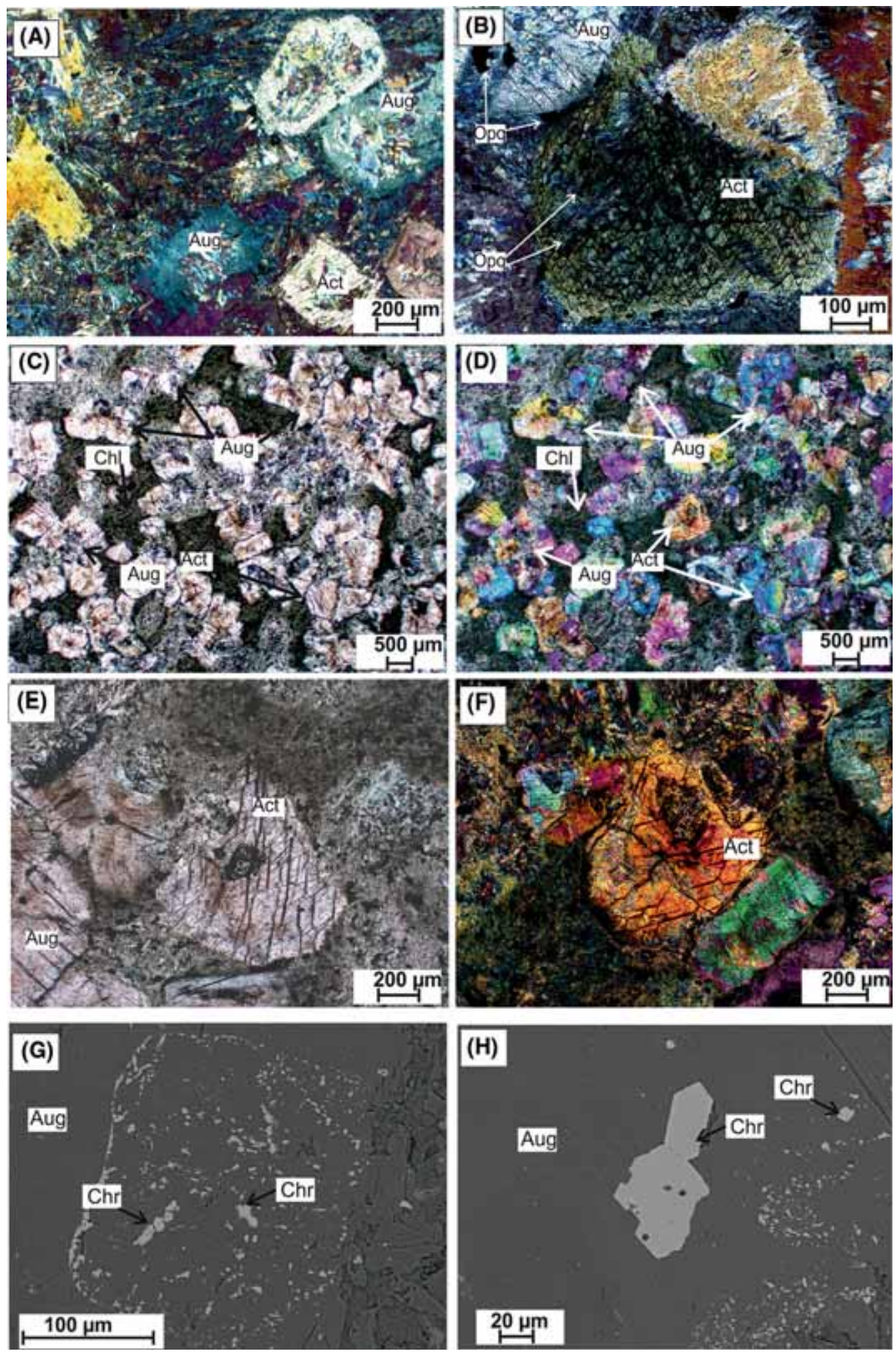

Figure 3. Photomicrographs showing textural and mineralogical variations in Polkampalli and Potepalli pyroxenites: (a) coarser twinned pyroxene surrounded by actinolite, chlorite and spinels (crossed polars), (b) actinolite-containing opaques along its cleavage (crossed polars), (c) overall textural view of the pyroxenites displaying subhedral augite and actinolite within the matrix of chlorite, actinolite-tremolite and opaque minerals (polarised light), (d) the same as c (crossed polars), (e) pyroxene grains associated with amphibole and spinels (polarised light), (f) same as e (crossed polars), (g) BSE image showing chromite inclusions in augite (crossed polars) and (h) BSE image showing euhedral chromite grain. (Abbreviations: Aug, augite; Act, actinolite; Chr, chromite; Opq, opaques). 

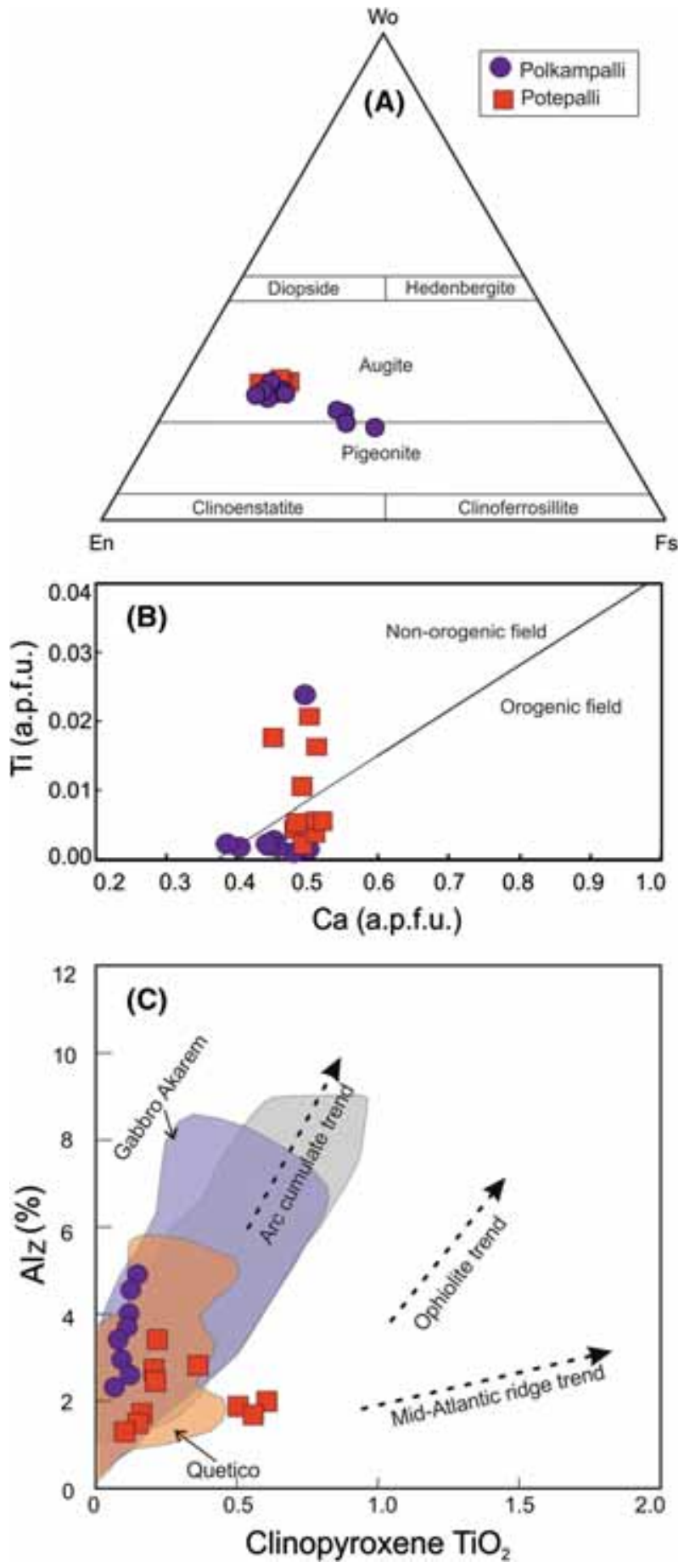

Figure 4. (a) Wo-En-Fo classification for pyroxene of this study (after Morimoto et al. 1988). (b) Ti (a.p.f.u.) vs. Ca (a.p.f.u.) plot (after Sun and Bertrad 1991) of clinopyroxene under study showing their orogenic affinity. (c) $\mathrm{TiO}_{2}$ vs. $\mathrm{Al}_{z}$ in clinopyroxene ( $\mathrm{Alz}$ refers to the percentage of $\mathrm{Al}$ in the tetrahedral sites $\left.\left(100^{*} \mathrm{Al} \mathrm{IV}\right) / 2\right)$. Data sources: Alaskan-type complexes from Quetico (Pettigrew and Hattori 2006); Gabbro Akarem (Helmy and El Mahallawi 2003); arc-cumulate field (Beard and Barker 1989). The trends for arc-cumulate field, ophiolite and mid-Atlantic ridge are after Loucks (1990).

\subsection{Amphibole}

The mineral chemistry data of the amphiboles is provided in table 2 . The amphiboles are essentially secondary (actinolite) with a very minor proportion of primary magnesio hornblende type, which are present as subhedral grains (figure 5a). Their secondary nature can also be deciphered in the $\mathrm{SiO}_{2}$ wt\% vs. $\mathrm{TiO}_{2}$ wt\% discriminatory plot (after Leake et al. 1997; figure 5b). In a plot of Si vs. $\mathrm{Na}+\mathrm{K}$ content, the hornblendes are indistinguishable from those reported from the Alaskan-type complex from the middle Tianshan massif, China (figure 5c).

\subsection{Spinel}

The mineral chemistry data of the spinel is provided in table 3 . In the Potepalli dyke, magnetite is the main oxide phase with $\mathrm{TiO}_{2}(0.22-0.60$ wt\%) showing little compositional variation. The Polkampalli dyke contains high to low titanium $\left(\mathrm{TiO}_{2}:\right.$ :0.09-45.78 wt\%) spinels, i.e., magnetite to the ilmenite type (figure 6). Spinels contain very less amounts of $\mathrm{MnO}$ (up to $0.48 \mathrm{wt} \%$ ) along with high $\mathrm{FeO}(23.83-99.86$ wt\%) and medium to low $\mathrm{Cr}_{2} \mathrm{O}_{3}$ (up to $20.21 \mathrm{wt} \%$; see table 3 ).

\subsection{Chromite}

The mineral chemistry data of chromite from the Polkampalli dyke is provided in table $4 . \mathrm{Cr}_{2} \mathrm{O}_{3}$ (50.63-53.46 wt\%) and $\mathrm{FeO}_{\mathrm{T}}(39.37-34.48 \mathrm{wt} \%)$ contents show slight variation, compared with that of $\mathrm{Al}_{2} \mathrm{O}_{3}$ (4.36-5.16 wt\%). The chemistry of the chromites played a crucial role in deciphering the magmatic character of this dyke and is discussed in detail in the subsequent section (see figures 7 and 8).

\subsection{Other phases}

The Polkampalli dyke also contains epidote and sulphides (pyrite, chalcopyrite, galena and chalcocite).

\section{Geochemistry}

\subsection{Major oxides}

Whole rock geochemistry of eight pyroxenite samples is presented in table 5. Samples show high loss on ignition (LOI) values (1.90-4.09 wt\%) 

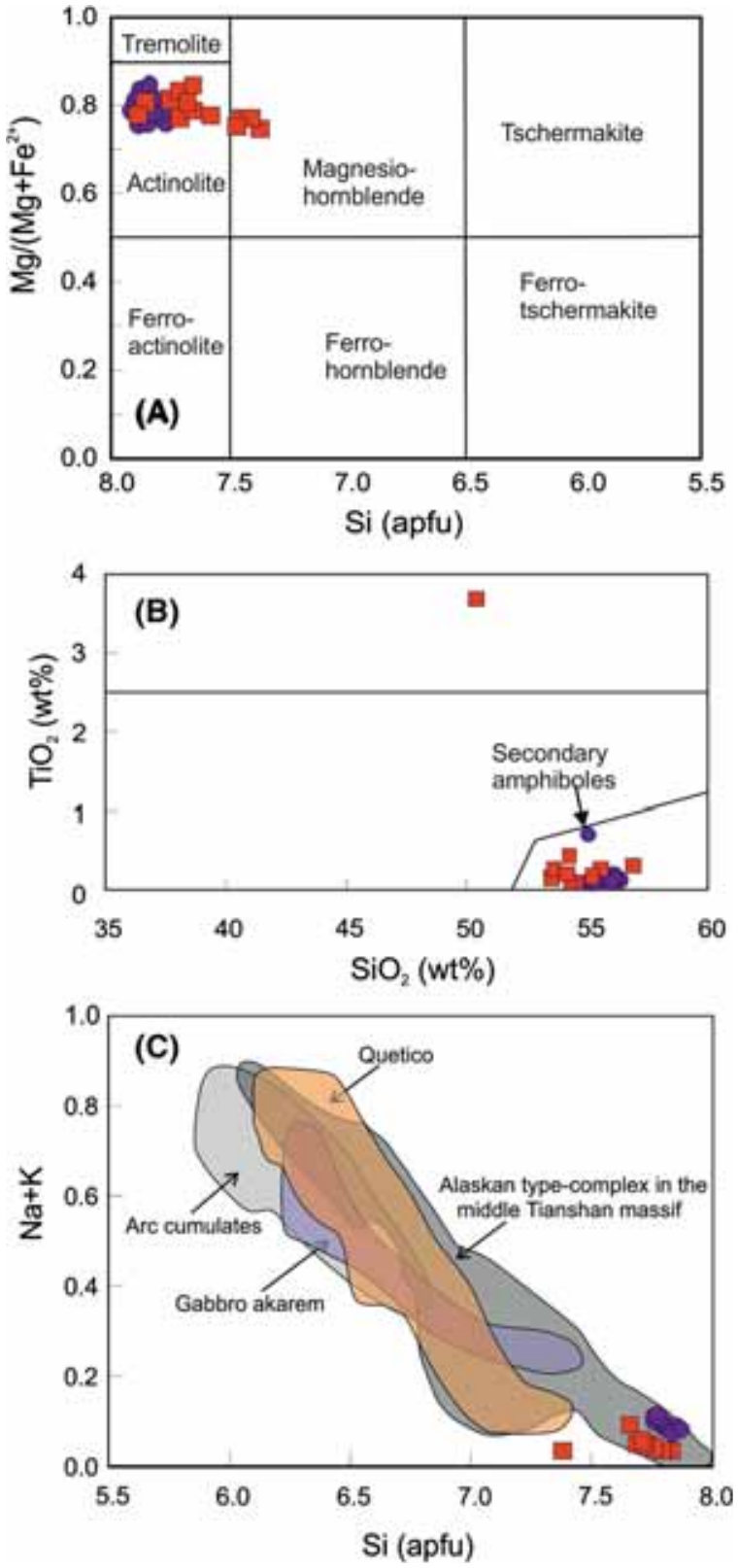

Figure 5. (a) Si vs. Mg\# plot for the classification of amphiboles (after Leake et al. 1997) from Polkampalli and Potepalli pyroxenites. (b) $\mathrm{TiO}_{2}$ (wt\%) vs. $\mathrm{SiO}_{2}$ (wt\%) plot (after Rock 1991) suggesting the secondary nature of amphiboles; (c) $\mathrm{Na}+\mathrm{K}$ vs. the Si content in the amphibole highlight the calc-alkaline nature of pyroxenites. The data for the Alaskantype complex in the middle Tianshan massif, China is from $\mathrm{Su}$ et al. (2012) and sources for other fields are the same as those given in figure 4. Symbols are the same as used in figure 4 .

which can be attributed to weathering and alteration. However, the consistency of major oxide patterns, high $\mathrm{Mg}$ number $(\mathrm{Mg} \#$ : 57-74) along with high $\mathrm{MgO}$ (8.38-19.47 wt\%) are indicative of their origin from a primary magma (Green 1971; Velasco-Tapia et al. 2001). All samples display limited geochemical variation between them and are

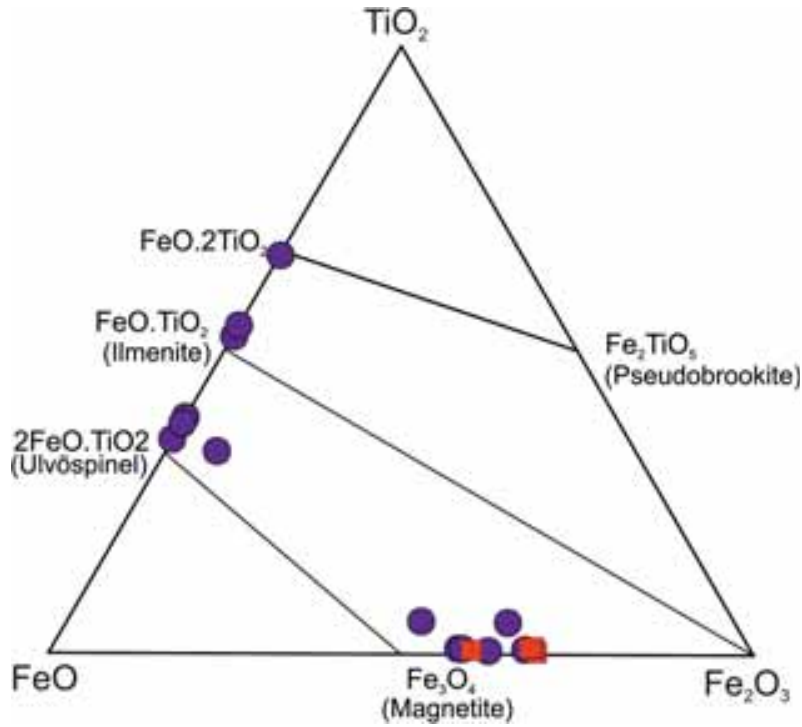

Figure 6. $\mathrm{FeO}-\mathrm{TiO}_{2}-\mathrm{Fe}_{2} \mathrm{O}_{3}$ ternary diagram showing the variation in spinel composition in the studied samples. The symbols are the same as those used in figure 4 .

comparable in terms of major oxides (figure 9). The concentration of $\mathrm{SiO}_{2}$ varies from 45.97 to $50.11 \mathrm{wt} \%$ and hence the samples can be termed as basic to ultrabasic, and in a few evolved samples, the $\mathrm{SiO}_{2}$ content decreases with the increase in $\mathrm{MgO}$ (figure 9a). In the AFM $\left(\mathrm{Na}_{2} \mathrm{O}+\right.$ $\mathrm{K}_{2} \mathrm{O}-\mathrm{FeO}-\mathrm{MgO}$ ) plot (not shown), the samples are confined to an arc-related mafic-ultramafic field. Negligible $\mathrm{K}_{2} \mathrm{O}$ and $\mathrm{Na}_{2} \mathrm{O}$ imply their non-potassic or non-sodic character, unlike the elevated occurrence of these oxides in the lamprophyres. It is well known that alkalis are prone to alteration and metamorphism whereas titanium and aluminium are the least mobile of the major elements (Pearce and Cann 1973; Floyd and Winchester 1975). $\mathrm{SiO}_{2}$, $\mathrm{Al}_{2} \mathrm{O}_{3}, \mathrm{CaO}, \mathrm{FeO}^{\mathrm{T}}$ and $\mathrm{TiO}_{2}$ vs. $\mathrm{Mg} \#$ (figure 10) indicates that these clinopyroxenites belong to the continental arc-cumulate type of origin (see Chin et al. 2018).

\subsection{Trace elements}

High values of $\mathrm{Ni}$ (up to $1070 \mathrm{ppm}$ ), Cr (up to $1300 \mathrm{ppm}$ ) and Co (up to $91 \mathrm{ppm}$ ) are generally considered to be good indicators of the derivation of parental magma from a peridotite mantle source (Herzberg 2004), whereas low Ce anomalies $\left(\mathrm{Ce} / \mathrm{Ce}^{*}=0.98-1.03\right)$ further negate the influence from fluid-assisted alteration and metamorphism (Polat and Hofmann 2003). Post-magmatic alterations can be understood by plotting the variation of different trace elements against a 

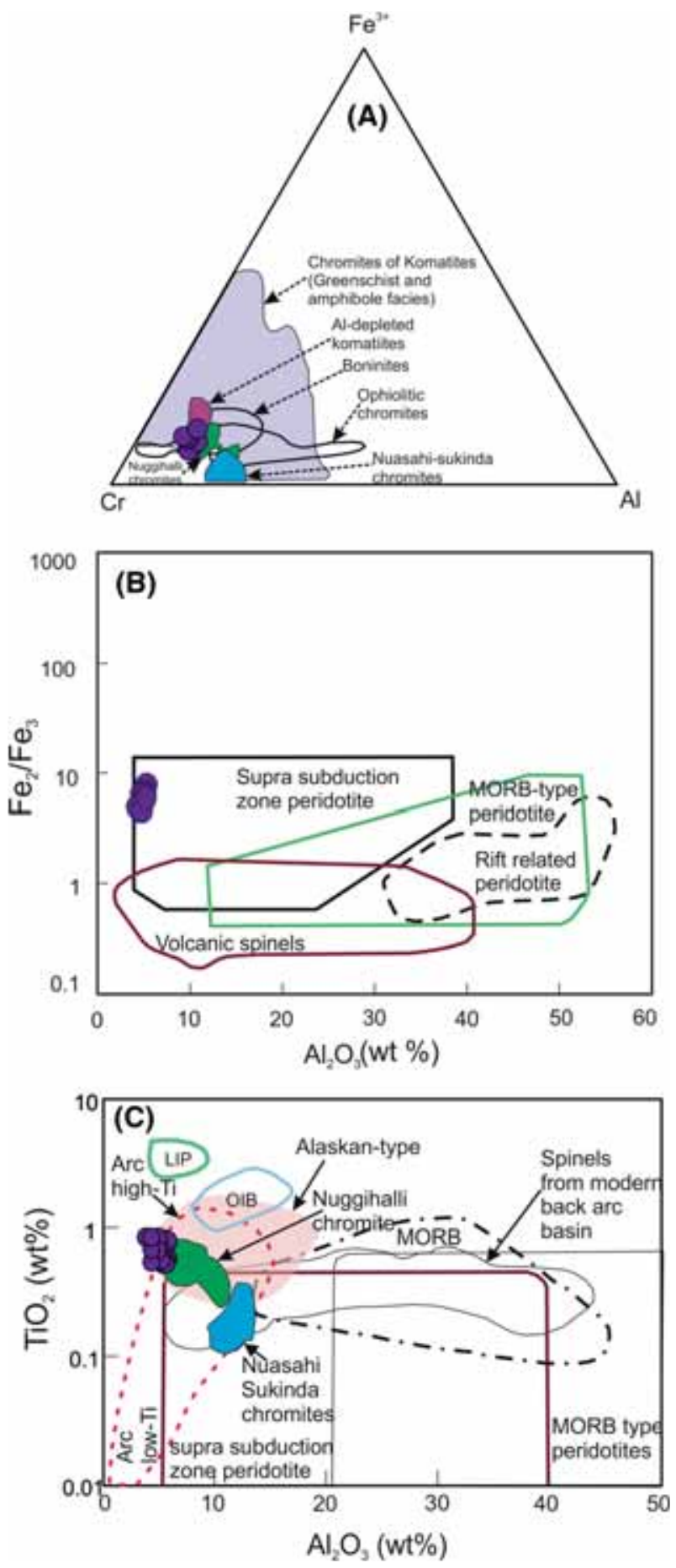

Figure 7. (a) $\mathrm{Al}-\mathrm{Cr}-\mathrm{Fe}^{3+}$ ternary plot for the chromites from the samples of this study. Fields of chromites associated with komatites, boninites, ophiolites Nuggihalli schist belt (Dharwar craton, southern India) and Nuasahi-Sukinda ultramafic complex (eastern India) are shown for comparison. Data sources: Nuggihalli chromites (Mukherjee et al. 2010), Nuasahi-Sukinda chromites (Mondal et al. 2006) and other fields are from Barnes and Roeder 2001. (b) $\mathrm{Fe}^{2+} / \mathrm{Fe}^{3+}$ vs. $\mathrm{Al}_{2} \mathrm{O}_{3}$ diagram for the chromites studied; data for Nuasahi-Sukinda chromites are taken from Mondal et al. (2006). (c) $\mathrm{TiO}_{2}$ vs. $\mathrm{Al}_{2} \mathrm{O}_{3}$ plot showing the arc-affinity of the chromites of this study; other fields are taken from Kamenetsky et al. (2001) and Manu Prasanth et al. (2017).
HFSE such as Zr. Zr is preferably used as the primary differentiation index to monitor the mobility of other major and trace elements as it is known to be almost immobile in response to post-magmatic hydrothermal alteration and metamorphism (Pearce et al. 1992; Polat and Kerrich 2000). To understand their relative mobility, various major oxides, large ion lithophile elements (LILEs) and HFSE are plotted against $\mathrm{Zr}$ (figure 11). In general, HFSE shows a relatively strong correlation than that displayed by LILE. The primordial mantle-normalised trace element plot (after Sun and McDonough 1989) shows high variation in LILE, which is an indication of the alteration due to metamorphism and late hydrothermal activities (figure 12a). On the other hand, the HFSE has a similar and restricted range (figure 12a). Variation in LILE distinguishes between the Polkampalli and the Potepalli samples whereas their HFSE contents are strikingly similar. Negative $\mathrm{Nb}$ and $\mathrm{Ta}$ anomalies for most of the samples suggest the involvement of subduction-related processes (Pearce 2008). The negative $\mathrm{Sr}$ anomaly can be interpreted to be indicative of source characteristic, owing to the depletion of mantle source in Sr during a previous phase of melt extraction (Tainton and McKenzie 1994). Trace element data of Potepalli and Polkampalli dykes show a strong similarity to those from Alaskan-type complexes rather than those from enriched mid-oceanic ridge basalt (E-MORB), normal mid-oceanic ridge basalts (NMORB) and oceanic island basalt (OIB) (figure 12a). The chondrite-normalised REE plot (figure 12b) of the two pyroxenite dykes shows a slight decrease from LREE to HREE without any negative spikes for Eu. There is a slight abundance in LREE over HREE, which is suggestive of a possible metasomatised source or garnet control in the source (Philpotts et al. 1972; Morten 1978; Ottonello et al. 1978). The pyroxenite dykes also display a similar trend in REE and show a strong overlap with the REE content of clinopyroxenites from the Alaskantype ultramafics (figure 12b).

\section{$5.3 \mathrm{Nd}$ and $\mathrm{Sr}$ isotopic geochemistry}

Measured $\mathrm{Nd}$ and $\mathrm{Sr}$ isotopic ratios of the two pyroxenite dykes are provided in table 6 . Initial isotopic ratios of these samples are calculated by assuming an emplacement age of $1.89 \mathrm{Ga}$ (see French et al. 2008), which is the timing of the emplacement of the mafic dyke swarms in the 

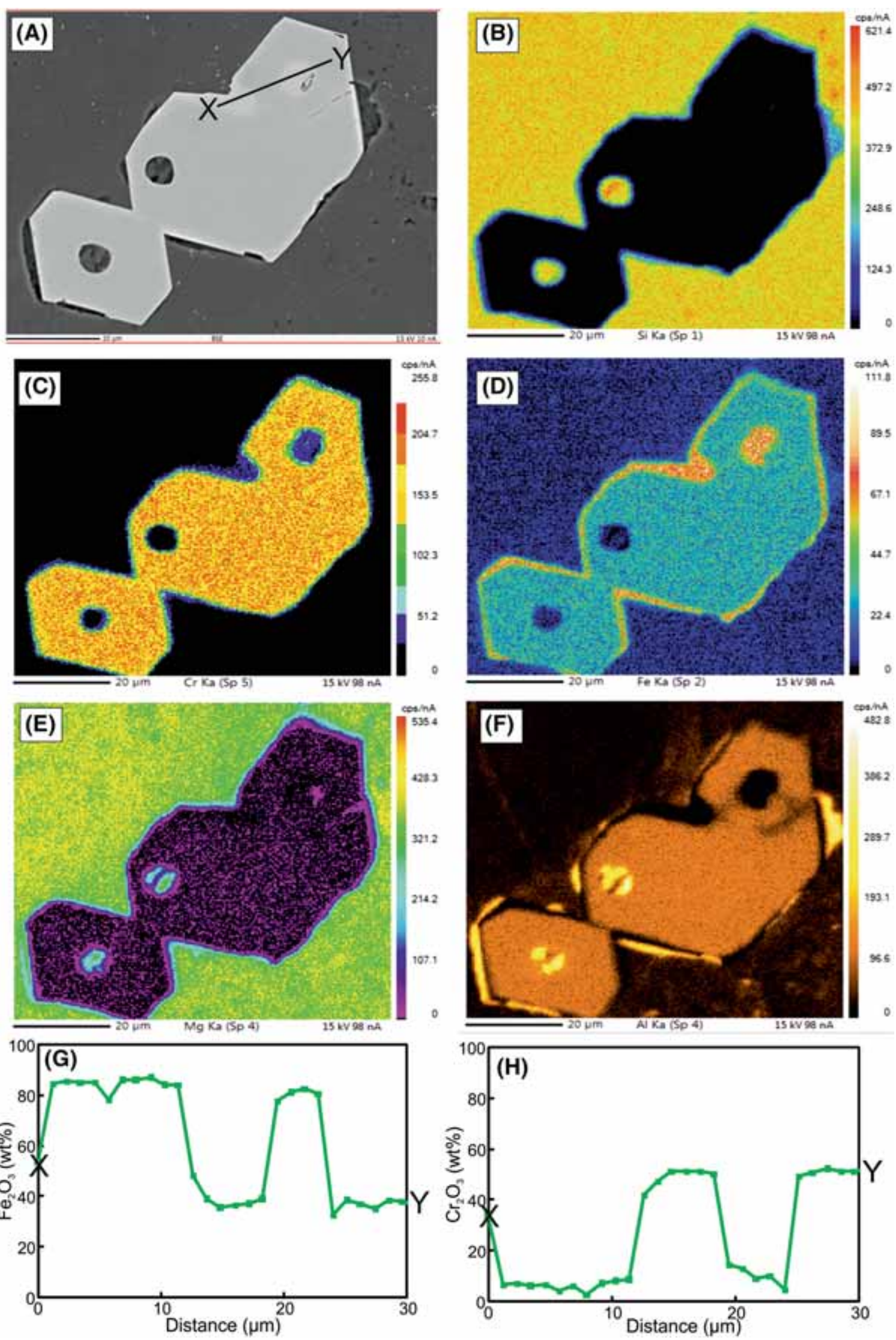

Figure 8. (a) Back-scattered electron (BSE) image showing zoned euhedral and the pristine nature of the chromite in the samples studied. Colour-coded X-ray element images of (b) silicon, (c) chromium, (d) iron, (e) magnesium and (f) aluminium in the chromites under study. Line scans of $(\mathbf{g}) \mathrm{Fe}_{2} \mathrm{O}_{3}$ and (h) $\mathrm{Cr}_{2} \mathrm{O}_{3}$ across a chromite grain along the $\mathrm{X}-\mathrm{Y}$ line. 

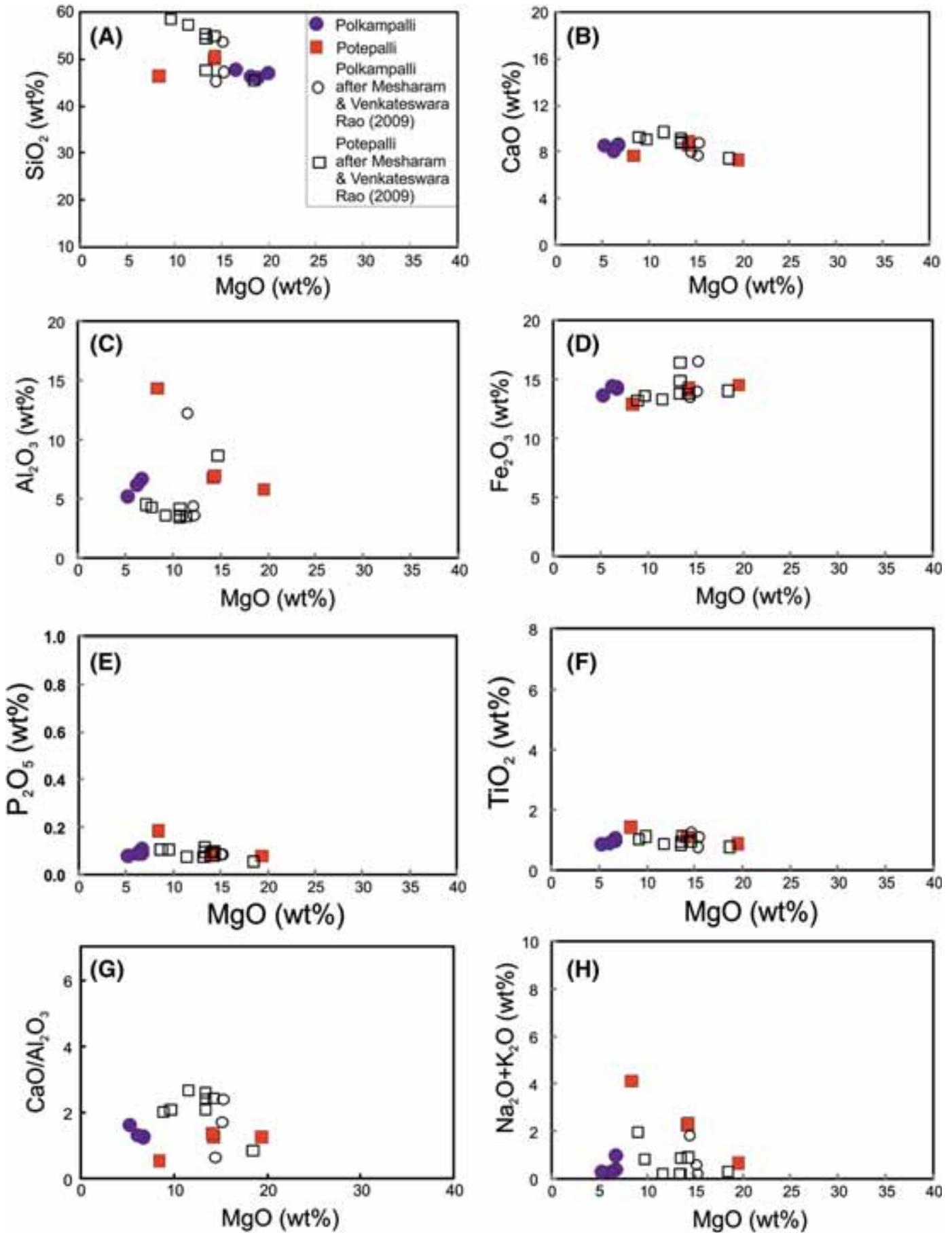

Figure 9. Major element variation vs. $\mathrm{MgO}$ for the Polkampalli and Potepalli pyroxenites. (a) $\mathrm{MgO}$ (wt\%) vs. $\mathrm{SiO} 2$ (wt\%), (b) $\mathrm{MgO}(\mathrm{wt} \%$ ) vs. $\mathrm{CaO}$ (wt\%), (c) $\mathrm{MgO}$ (wt\%) vs. $\mathrm{Al} 2 \mathrm{O} 3$ (wt\%), (d) $\mathrm{MgO}$ (wt\%) vs. $\mathrm{Fe} 2 \mathrm{O} 3$ (wt\%), (e) $\mathrm{MgO}$ (wt\%) vs. $\mathrm{P} 2 \mathrm{O} 5$ (wt\%), (f) $\mathrm{MgO}(\mathrm{wt} \%$ ) vs. $\mathrm{TiO} 2$ (wt\%), (g) $\mathrm{MgO}(\mathrm{wt} \%$ ) vs. $\mathrm{CaO} / \mathrm{Al} 2 \mathrm{O} 3$, and (h) $\mathrm{MgO}$ (wt\%) vs. $\mathrm{Na} 2 \mathrm{O}+\mathrm{K} 2 \mathrm{O}$ (wt\%). Data for Polkampalli and Potepalli pyroxenites published earlier by Meshram and Venkateswara Rao (2009) are also provided.

Dharwar craton as well as that of the mafic sills within the Cuddapah basin. ${ }^{87} \mathrm{Sr} /{ }^{86} \mathrm{Sr}_{\text {initial }}$ $(0.711682$ and 0.705386$)$ and negative $\varepsilon \mathrm{Nd}_{\text {initial }}$ $(-5.9$ and -9.9$)$ of the studied samples share a similarity with those of Xiadong mafic-ultramafics ( $\mathrm{Su}$ et al. 2014) and to Tarim block layered intrusion, NW China (Zhang et al. 2011) (figure 13). It can be also seen that the ${ }^{87} \mathrm{Sr} /{ }^{86} \mathrm{Sr}_{\text {initial }}$ values are of the studied samples are high and resemble those of the subduction-related Western Australian lamproites (Nelson 1989). In the $\varepsilon \mathrm{Nd}_{\text {initial }}$ vs. $100 / \mathrm{Nd}$ plot (figure 13), the composition of the studied samples are similar to those of Tarim block layered intrusion and Alaskan-type intrusion from the north 

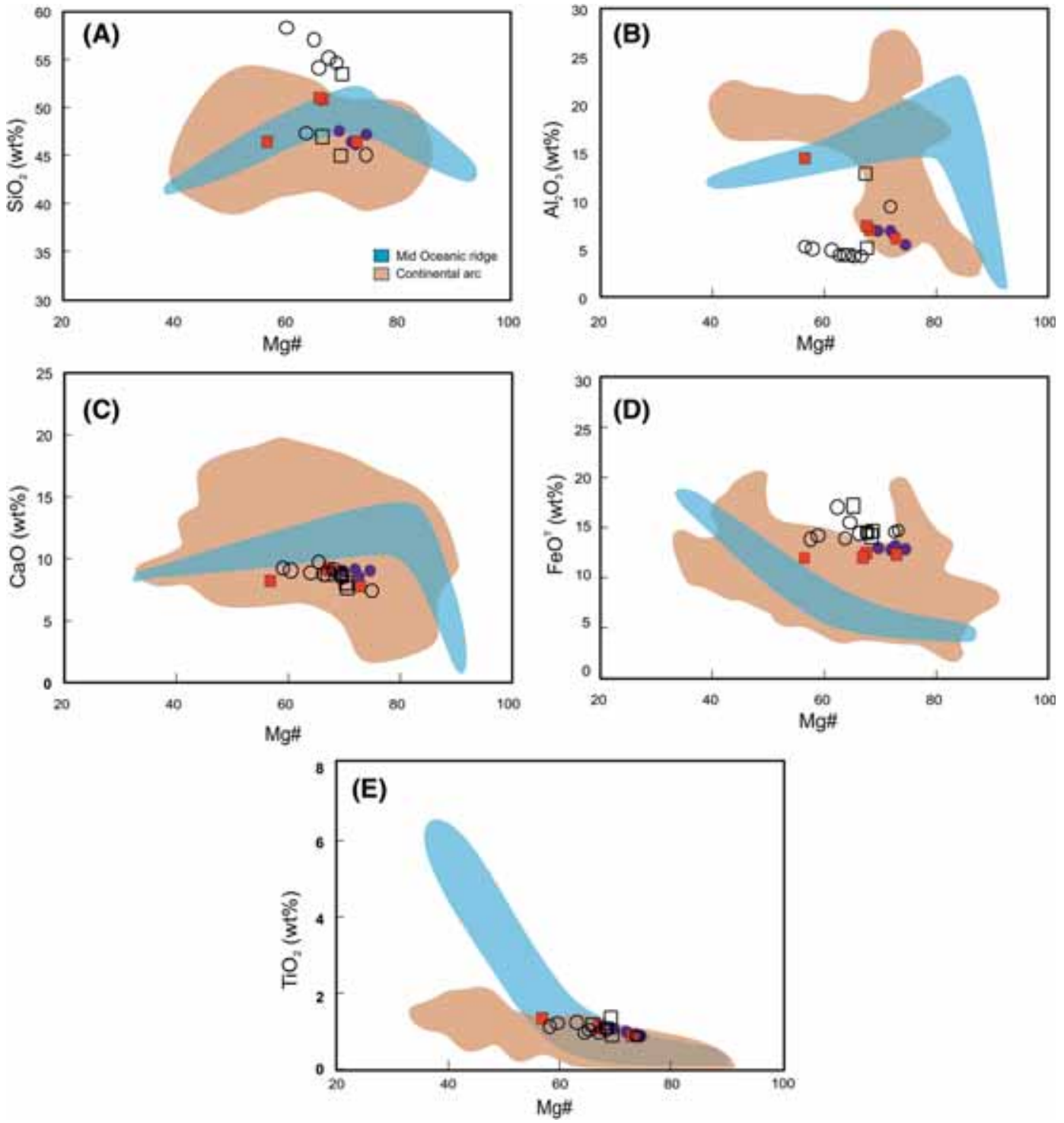

Figure 10. $\mathrm{Mg} \#$ vs. the major oxide plot of $\mathrm{Mg} \#$ vs. (a) $\mathrm{SiO}_{2}\left(\mathrm{wt} \%\right.$ ); (b) $\mathrm{Al}_{2} \mathrm{O}_{3}\left(\mathrm{wt} \%\right.$ ); (c) $\mathrm{CaO}(\mathrm{wt} \%) ;(\mathbf{d}) \mathrm{FeO}^{\mathrm{T}}$ (wt\%); (e) $\mathrm{TiO}_{2}$ (wt\%). Fields for mid-oceanic ridge cumulate and continental arc cumulate are taken from Chin et al. (2018). Symbols and data sources are the same as those in figure 9.

China craton (Yuan et al. 2017). Depleted mantle model ages $\left(T_{\mathrm{DM}}=2.70-3.44 \mathrm{Ga}\right)$ of the studied pyroxenites show that the mantle source enriched during the Meso-Neoarchaean.

\section{Petrogenesis}

\subsection{Crustal contamination vs. subduction zone-derived fluid enrichment}

It is imperative to evaluate post-magmatic metamorphism and alteration overprinting effects before discussing mantle source and petrogenesis of mantle-derived rocks. After carefully assessing various parameters, viz., field setting (igneous character), petrography, and bulk-rock geochemistry, we infer that these rocks have not been significantly affected by metamorphic and alteration processes. Therefore, primary igneous processes are considered to exercise a dominant control on their present chemical composition. The presence of zoned and pristine chromites further negates any intensive overprinting effect. However, the presence of olivine pseudomorphs along with secondary amphiboles (actinolite and tremolite) suggests effects of a slight alteration. High $\mathrm{Mg}$ number $(\mathrm{Mg} \#>70)$, Ni (>500 ppm), Cr (>1000 ppm), Sc (15-30 ppm) and Co (25-30 ppm) together with intermediate-to-low $\mathrm{SiO}_{2}(<50 \mathrm{wt} \%)$ are considered to be typical of primary magmas (Foley 

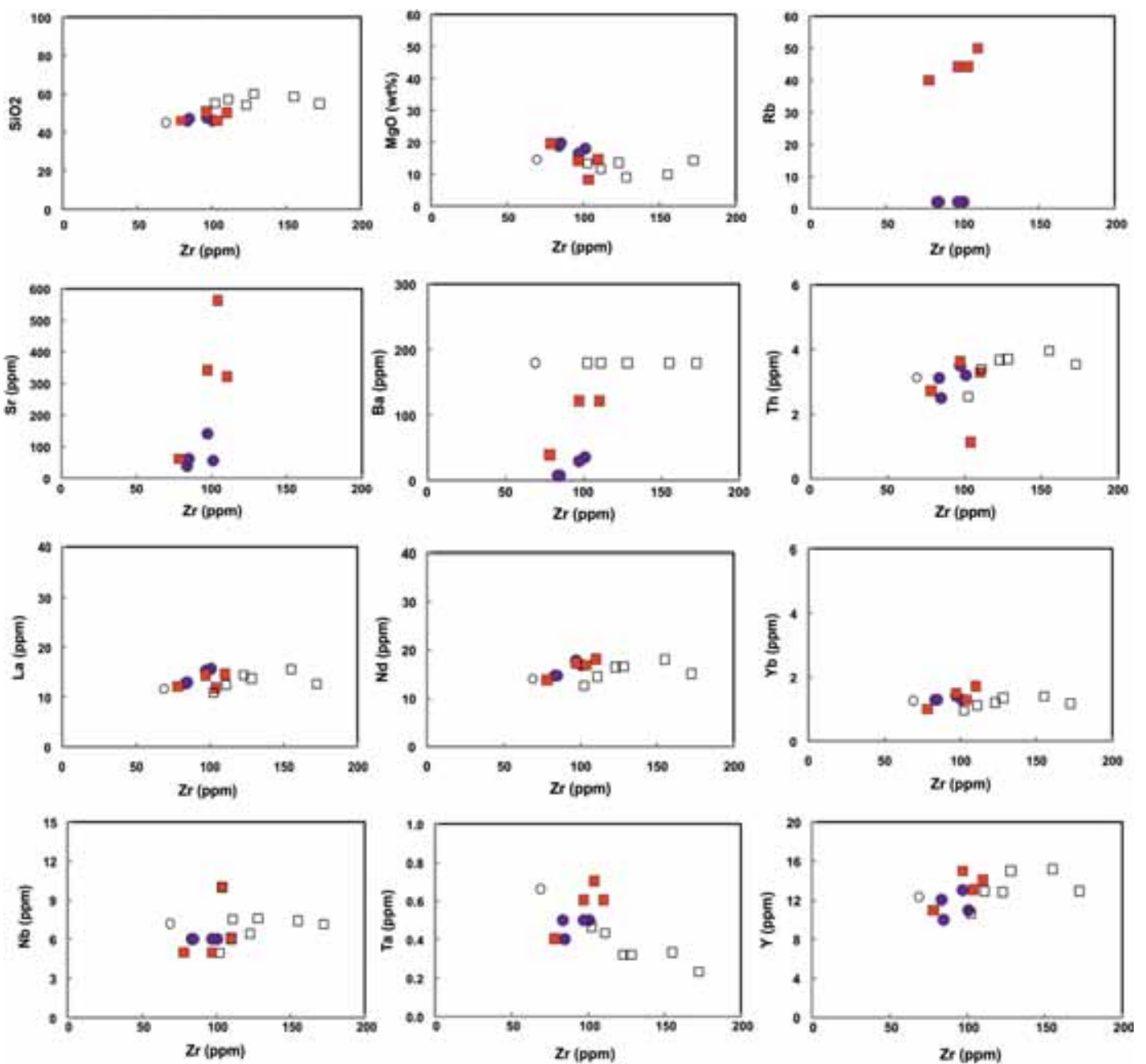

Figure 11. Trace element variations vs. Zr for the samples under study. Symbols and data sources are same as those in figure 9 .

et al. 1987). LOI is essentially $<4.2$, suggesting limited influence from fluid-assisted alteration and metamorphism (see Polat and Hofmann 2003; Yuan et al. 2017). The samples under study show little $\mathrm{SiO}_{2}$ variation from 47.69 to 50.11 wt\% and, together with $\mathrm{MgO}(8.38-19.47 \mathrm{wt} \%), \mathrm{Mg} \#$ (57-74), Ni (230-1120 ppm), Co (58-97 ppm) and $\mathrm{Cr}$ (370-1300 ppm) (see table 5), are consistent with the signatures of the primary magmas. Crustal material would increase the $\mathrm{K}_{2} \mathrm{O}$ and $\mathrm{Na}_{2} \mathrm{O}$ content of the melt undergoing crustal contamination. Low $\mathrm{K}_{2} \mathrm{O}(0.03-1.23$ wt\%) and $\mathrm{Na}_{2} \mathrm{O}(0.20-2.91 \mathrm{wt} \%)$ contents of the studied samples, therefore, exclude the role of significant crustal contamination. Likewise, a coherent variation of LILE, HFSE and REE patterns and primitive mantle-normalised multi-element plots negates extensive alteration and/or crustal contamination (Middelburg et al. 1988). Low HREE and Y contents along with the lack of positive Eu anomaly in the chondrite normalised REE patterns and the presence of negative Sr anomaly in the primitive mantle-normalised multi-element plots further argue against extensive crustal assimilation. This is further corroborated by the Th/La ratio $(0.09-0.25)$ of the studied samples, which is slightly higher than that of the primitive mantle ( 0.12; Sun and McDonough 1989) and Nb/Y (0.33-0.77) which is slightly lower than that of the lower continental crust $(\sim 0.7$, Weaver and Tarney 1984), and suggests a limited crustal contamination. On the other hand, the $(\mathrm{Hf} / \mathrm{Sm})_{N}$ vs. $(\mathrm{Ta} / \mathrm{La})_{N}$ plot (figure 14) suggests the involvement of fluid-related subduction metasomatism. Thus, despite some degrees of alteration, crustal contamination and fluid-related metasomatism, the studied pyroxenites retain their overall igneous character highlighting their bulk-rock geochemistry to be of petrogenetic significance. 

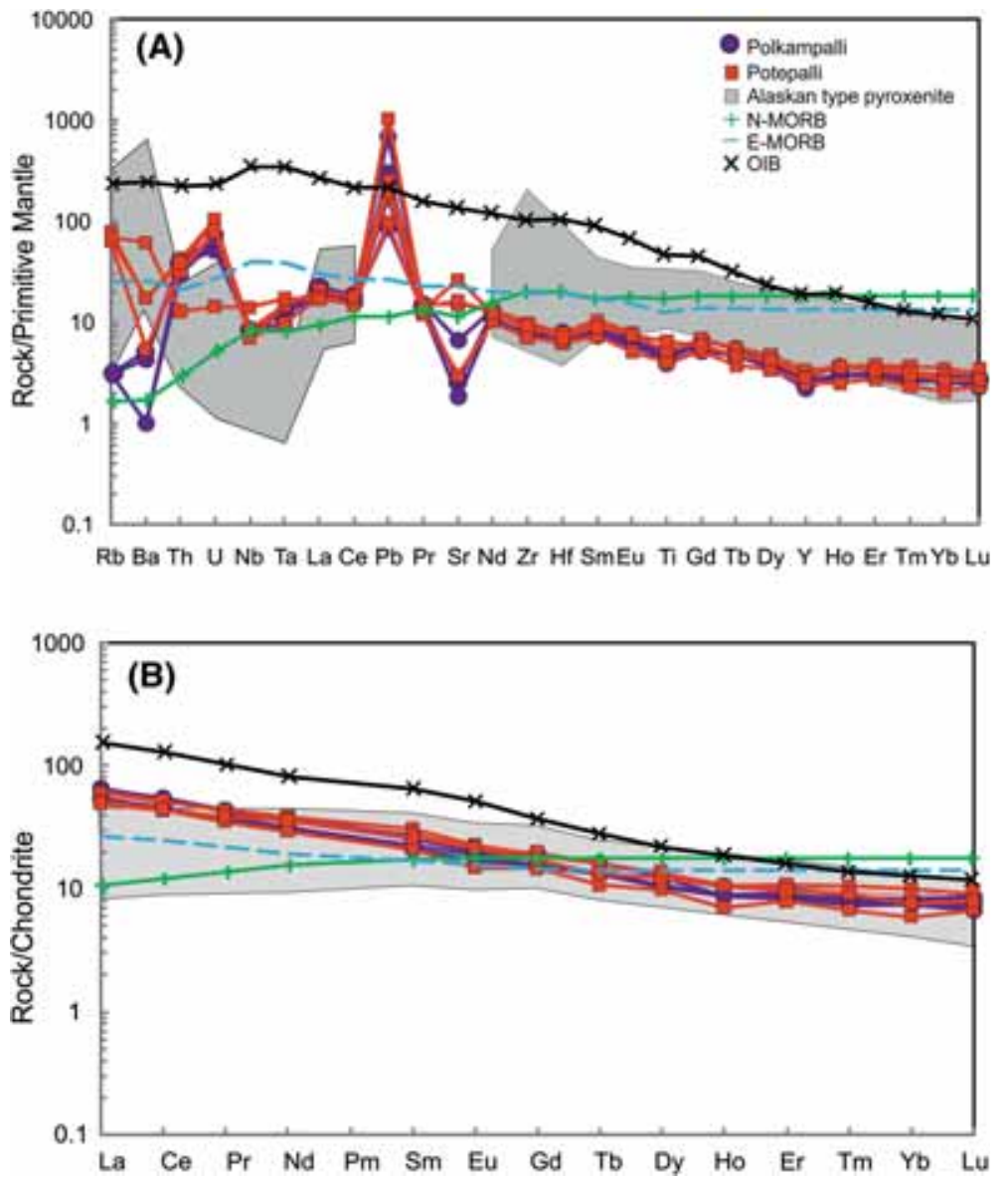

Figure 12. (a) Primitive mantle-normalised trace element diagrams for the pyroxenites of this study. Normalisation values are from Sun and McDonough (1989). The data for OIB and E-MORB are also from Sun and McDonough (1989). The data of pyroxenites from the Alaskan-type complexes are taken from Himmelberg and Loney (1995). (b) Chondrite-normalised REE patterns for the samples of this study. Normalisation values are from Sun and McDonough (1989). The data for pyroxenites from the Alaskan-type complexes are taken from Himmelberg and Loney (1995).

\subsection{Chromite chemistry - key for understanding mantle source}

Chromites are known to share a close relationship with deep-seated ultrabasic rocks and are widely considered as the strongest illustrations of early magmatic crystallisation (Barnes 1998). Several controlling factors such as the degree of melting of the mantle source, fractional crystallisation and mantle residue-magma interactions between peridotite and basaltic melt and post-magmatic processes are known to control the composition of chromite (Al-Boghdady and Economou-Eliopoulos 2005). Chromites in this study are very rich in chromium content relative to that of iron; and in $\mathrm{Fe}^{3+}$ vs. Cr vs. Al (figure 7a), they are confined to the compositional field of chromites from greenschist and amphibolite facies together with chromites from the Nuggihalli schist belt, Dharwar craton. In the $\mathrm{Al}_{2} \mathrm{O}_{3}$ vs. $\mathrm{Fe}^{2+} / \mathrm{Fe}^{3+}$ plot (figure $7 \mathrm{~b}$ ), the studied chromites plot in a supra-subduction setting. This is also consistent with their primitive mantle-normalised multi-element plot (figure 12a), where negative $\mathrm{Nb}$ and $\mathrm{Ta}$ anomalies are present indicating a subduction tectonic setting. Chromites of this study are more ferriferous and less aluminous in nature with a $\mathrm{Cr}$ :Fe ratio of about $2: 1$ and have stratiform-type chromite signatures. In the $\mathrm{TiO}_{2}$ vs. $\mathrm{Al}_{2} \mathrm{O}_{3}$ plot (see figure $7 \mathrm{c}$ ), the studied chromites plot in the field of Alaskan-type ultramafics as well as in supra-subduction zone peridotites.

An X-ray map of the elements $\mathrm{Cr}, \mathrm{Fe}, \mathrm{Si}, \mathrm{Mg}$ and $\mathrm{Al}$ in chromite, together with their BSE images, are presented in figure 8 . The BSE image displays a very sharp zoning from core to the rim of chromite. $\mathrm{X}$-ray element 'dot' mapping clearly delineates that the rim is relatively iron-rich, while its core is more chromium-rich. $\mathrm{Mg}$ and $\mathrm{Si}$ contents are very negligible, while there is a slight presence of $\mathrm{Al}$. The 


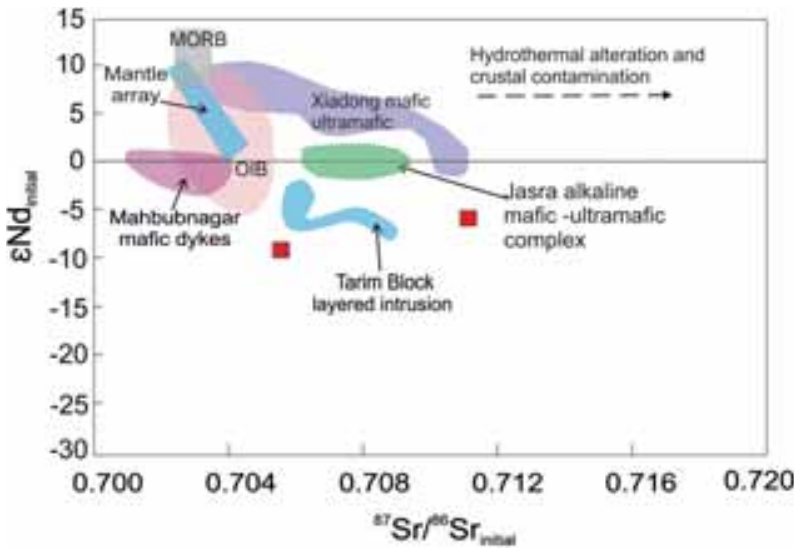

Figure 13. $\varepsilon \mathrm{Nd}_{\text {initial vs. }}{ }^{87} \mathrm{Sr} /{ }^{86} \mathrm{Sr}_{\text {initial }}$ Other data sources: Alaskan-type intrusion from the North China craton is taken from Yuan et al. (2017); Xiadong mafic ultramafics, China are taken from Su et al. (2014); Tarim block layered intrusions, China are taken from Zhang et al. (2011); Jasra Mafic Ultramafic complexes are taken from Srivastava and Sinha (2007); Mahbubnagar mafic dykes are taken from Pandey et al. (1997); MORB is taken from Nelson (1989).

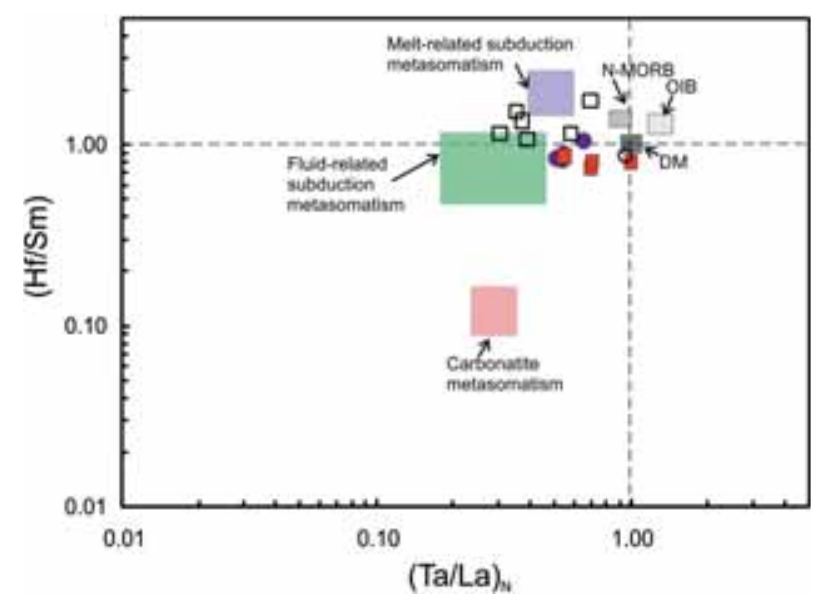

Figure 14. $(\mathrm{Hf} / \mathrm{Sm})_{N}$ vs. $(\mathrm{Ta} / \mathrm{La})_{N}$ diagram (after La Flèche et al. 1998) suggesting fluid-related metasomatism of the mantle source region of the samples under study. Symbols and data sources remain the same as those in figure 9 .

line scan, plotted along the $\mathrm{X}-\mathrm{Y}$ line as shown in figure 8 , depicts a reciprocal relationship between ferric iron and chromium, suggesting that iron is replacing chromium.

\subsection{Mantle source region}

The fact that the primary minerals present in the rocks have been mostly altered to the actinolitetremolite association, and the absence of fresh olivine precludes the evaluation of the composition of the primary magma that equilibrated with its mantle source. A positive correlation of $\mathrm{Sm} / \mathrm{Yb}$ with Sm (figure 15) indicates the role played by

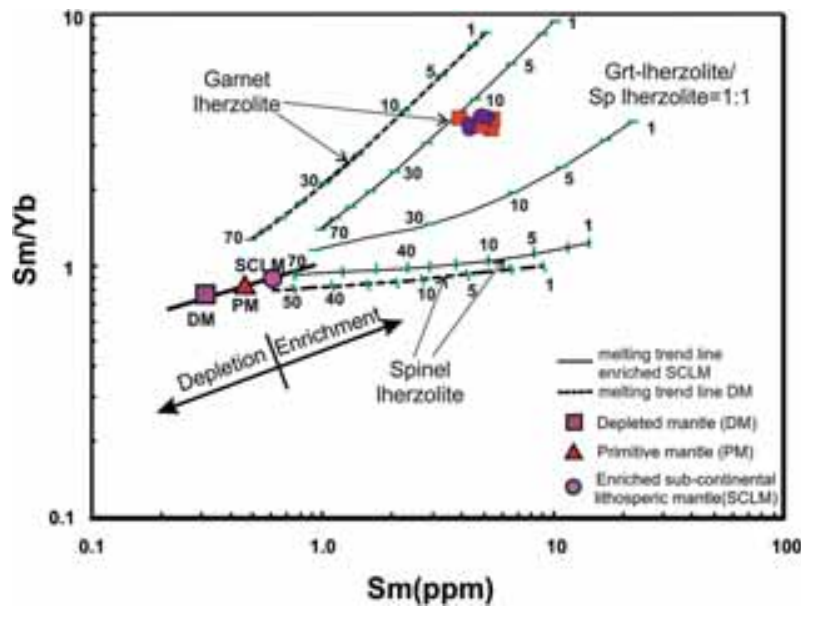

Figure 15. Sm/Yb vs. Sm plot for the studied samples (after Aldanmaz et al. 2000). Non-modal batch melting equation of Shaw (1970) was used for the calculation of melting curves for garnet lherzolite and spinel lherzolite. The dashed and solid lines are the melting trajectories for the depleted mantle $(\mathrm{DM}, \mathrm{Sm}=0.3 \mathrm{ppm}$ and $\mathrm{Sm} / \mathrm{Yb}=0.86$; McKenzie and O'Nions 1991) and enriched subontinental lithospheric mantle (SCLM, Sm $=0.6 \mathrm{ppm}$ and $\mathrm{Sm} / \mathrm{Yb}=0.96$; Aldanmaz et al. 2000), respectively. Partition coefficients used in the modelling are from the compilation of McKenzie and O'Nions (1991). Degrees of partial melting based on a given source are shown as marks on the curves.

partial melting in the dykes under study. High $\mathrm{Mg} \#$, Ni, Cr and Co along with a low concentration of $\mathrm{Al}_{2} \mathrm{O}_{3}$ and $\mathrm{TiO}_{2}$ as well as the negative slope of HREE suggest a highly refractory source such as the depleted mantle source (Tainton and McKenzie 1994; Beard et al. 2000). (Hf/Sm $)_{N}$ vs. $(\mathrm{Ta} / \mathrm{La})_{N}$ plot (figure 14) is suggestive of fluid-related subduction metasomatism of a depleted mantle garnet peridotite source. It is possible to track the magmatic chemistry of the studied pyroxenite dykes by comparing their observed REE pattern with those calculated for residue produced by the partial melting of a chosen source material viz., hydrous garnet-bearing lherzolite (Miller et al. 1999). For this, we have calculated the melting curves using different starting materials as possible sources (garnet lherzolite, garnet-spinel lherzolite and spinel lherzolite). Our modelling results (figure 15) show that the generation of these pyroxenites melt can be explained by 10-20\% partial melting of a fertile lithospheric mantle source. The $\mathrm{Sm} / \mathrm{Yb}$ vs. Sm plot indicates a strong evidence for garnet lherzolite, rather than spinel lherzolite, as a source. It can also be clearly seen from the $\mathrm{Nb}$ and $\mathrm{Ta}$ anomalies, and chromite compositions that the studied clinopyroxenites are similar to those of ultramafics from supra-subduction zones. In fact, available petrogenetic models for the supra-subduction type 
and Alaskan-type intrusions strongly favour a $\mathrm{Mg}$ rich hydrous parental magma (e.g., Irvine 1974; Himmelberg and Loney 1995; Burg et al. 2009; Eyuboglu et al. 2010; Cai et al. 2012; Sappin et al. 2012; Helmy et al. 2014; Su et al. 2012, 2014), in accordance with our proposed model.

\section{Tectonomagmatic implications}

Geodynamic evolution of the Dharwar craton is widely debatable (see Jayananda et al. 2018 and references therein), even though it constitutes one of the extensively studied terrains of the Indian shield. Various models have been proposed advocating the preservation of a subduction component, from Neoarchaean to $1.6 \mathrm{Ga}$, in the SCLM below the eastern Dharwar craton (Chadwick et al. 2000; Chardon et al. 2002; Harish Kumar et al. 2003; Mishra and Prajapati 2003; Naqvi et al. 2006; Manikyamba and Kerrich 2012; Das Sharma and Ramesh 2013; Jayananda et al. 2013; Ram Mohan et al. 2013; Pandey et al. 2017a,b). As discussed above, the Alaskan-type ultramafic rocks are considered to be products of the continental magmatic arc system (e.g., Taylor (1967); Irvine 1974; Himmelberg and Loney 1995; Helmy and El Mahallawi 2003; Pettigrew and Hattori 2006; Sappin et al. 2012; Helmy et al. 2014; Su et al. 2014; Yuan et al. 2017). Recently, a subduction-linked SCLM in the Dharwar craton has been attributed as a source for the post-collision calc-alkaline and shoshonitic lamprophyres from the Mudigubba and the Udiripikonda areas, respectively (figure 1), near the western margin of the Cuddapah basin (Pandey et al. 2017a, b). Our present study demonstrates that studied pyroxenite dykes were generated from the decompression partial melting of a fertile mantle metasomatised possibly during the Neoarchaean subduction event. Therefore, we propose that a fossil subducted component is likely to be present all along the western margin of the Cuddapah basin in the Dharwar craton. Further studies on magmatic rocks, on these lines, in this domain are required to further evaluate this proposal.

\section{Conclusions}

The following major conclusions can be drawn from this study:

- The ultramafic Kalwakurthy dykes (both Polkampalli and Potepalli occurrences) are clinopyroxenites having a cumulate texture, and not lamprophyres as reported earlier. Bulk geochemistry suggests they are continental arc-related cumulates.

- Their chromite composition, bulk-rock trace element content and $\mathrm{Sr}-\mathrm{Nd}$ isotopic compositions imply the involvement of subduction-related processes in their genesis; in this regard, they are strikingly similar to those of the Alaskan-type pyroxenites reported from the supra-subduction type of tectonic setting.

- Trace element ratios viz., Hf/Sm, Ta/La, of the studied dykes are suggestive of a fluid-related metasomatism influencing their source regions.

- Petrogenetic modelling reveals that $10-20 \%$ partial melting of the fertile lithospheric mantle source can generate the observed compositions of the two pyroxenite dykes.

\section{Acknowledgements}

The authors are grateful to the Head of the department of Geology, BHU for the support. This work is an outcome of a major project (IR/S4/ESF$18 / 2011$ dated 12.11.2013) on the evolution of the mantle beneath the Indian cratons and mobile belts sanctioned to NVCR by DST-SERB, New Delhi. RKG is thankful to the UGC for financial support. The authors gratefully acknowledge the insightful reviews by two anonymous journal reviewers and the useful suggestions by the handling editor Prof. R Bhutani.

\section{References}

Al-Boghdady A and Economou-Eliopoulos M 2005 Fluid inclusions in chromite from a pyroxenite dike of the Pindos ophiolite complex; Chem. Erde-Geochem. 65 191-202.

Aldanmaz E, Pearce J A, Thirlwall M F and Mitchell J G 2000 Petrogenetic evolution of late cenozoic, postcollision volcanism in western Anatolia, Turkey; J. Volcanol. Geotherm. Res. 102 67-95.

Allégre C J and Turcotte D L 1986 Implications of a 2component marble-cake mantle; Nature 323 123-127.

Aulbach S and Jacob D E 2016 Major- and trace-elements in cratonic mantle eclogites and pyroxenites reveal heterogeneous sources and metamorphic processing of low-pressure protoliths; Lithos 262 586-605.

Banerjee A, Chakrabarti R and Mandal S 2016 Geochemical anatomy of a spheroidally weathered diabase; Chem. Geol. 440 124-138.

Barnes S J 1998 Chromite in komatiites, magmatic control on crystallization and composition; J. Petrol. 39(11) 1689-1720.

Beard J S and Barker F 1989 Petrology and tectonic significance of gabbros, tonalities, shoshonites and anorthosites 
in a late Paleozoic arc-root complex in the Wrangellia terrane, southern Alaska; J. Geol. 97 667-683.

Beard A D, Downes H, Hegner E and Sablukov S M 2000 Geochemistry and mineralogy of kimberlites from the Arkhangelsk region, NW Russia: Evidence for transitional kimberlite magma types; Lithos 51 47-73.

Barnes S J and Roeder P L 2001 The range of spinel compositions in terrestrial mafic and ultramafic rocks; J. Petrol. 42(12) 2279-2302.

Bodinier J L, Fabries J, Lorand J P, Dostal J and Dupuy C 1987 Geochemistry of amphibole pyroxenite veins from the Lherz and Freychinède ultramafic bodies; Bull. Mineral. $110345-358$.

Burg J P, Bodinier J L, Gerya T, Bedini R M, Boudier F, Dautria J M, Prikhodko V, Efimov A, Pupier E and Balanec J L 2009 Translithospheric mantle diapirism: Geological evidence and numerical modelling of the Kondyor zoned ultramafic complex (Russian Far-East); J. Petrol. 50 289-321.

Cai K, Sun M, Yuan C, Zhao G, Xiao W and Long X 2012 Keketuohai maficultramafic complex in Chinese Altai, NW China: Petrogenesis and geodynamic significance; Chem. Geol. 294-295 26-41.

Chadwick B, Vasudev V N and Hegde G V 2000 The Dharwar craton, southern India, interpreted as the result of late Archaean oblique convergence; Precamb. Res. 99 91-111.

Chalapathi Rao N V, Wu F Y, Mitchell R H, Li L Q and Lehmann B 2013 Mesoproterozoic U-Pb ages, trace element and $\mathrm{Sr}-\mathrm{Nd}$ isotopic composition of perovskite from kimberlites of the Eastern Dharwar craton, southern India: Distinct mantle sources and a widespread 1.1 Ga tectonomagmatic event; Chem. Geol. 353 48-64.

Chalapathi Rao N V, Kumar A, Sahoo S, Dongre A N and Talukdar D 2014 Petrology and petrogenesis of Mesoproterozoic lamproites from the Ramadugu field, NW margin of the Cuddapah basin, Eastern Dharwar craton, southern India; Lithos 196-197 150-168.

Chardon D, Peucat J J, Jayananda M, Choukroune P and Fanning C M 2002 Archean granite-greenstone tectonics at Kolar (South India): Interplay of diapirism and bulk inhomogenous shortening during juvenile magmatic accretion; Tectonics 21(3) 1016. https://doi.org/10.1029/ 2001TC901032.

Chin E J, Shimizu K, Bybee G M and Erdman M E 2018 On the development of the calc-alkaline and tholeiitic magma series: A deep crustal cumulate perspective; Earth Planet. Sci. Lett. 482 277-287.

Das Sharma S and Ramesh D S 2013 Imaging mantle lithosphere for diamond prospecting in southeast India; Lithosphere 5 331-342.

Dharma Rao C V and Santosh M 2011 Continental arc magmatism in a Mesoproterozoic convergent margin: Petrological and geochemical constraints from the magmatic suite of Kondapalle along the eastern margin of the Indian plate; Tectonophysics $\mathbf{5 1 0}$ 151-171.

Dick H J B and Sinton J M 1979 Compositional layering in Alpine peridotites: Evidence for pressure solution creep in the mantle; J. Geol. 87 403-416.

Downes H 2007 Origin and significance of spinel and garnet pyroxenites in the shallow lithospheric mantle: Ultramafic massifs in orogenic belts in Western Europe and NW Africa; Lithos 99 1-24.
Eyuboglu Y, Dilek Y, Bozkurt E, Bektas O, Rojay B and Sen C 2010 Structure and geochemistry of an Alaskantype ultramafic-mafic complex in the Eastern Pontides, NE Turkey; Gondwana Res. 18 230-252.

Floyd P A and Winchester J A 1975 Magma type and tectonic setting discrimination using immobile elements; Earth Planet. Sci. Lett. 27 211-218.

Foley S F, Venturelli G, Green D H and Toscani L 1987 The ultrapotassic rocks: Characteristics, classification and constraints for petrogenetic models; Earth Sci. Rev. 24 81-134.

French J E, Heaman L M, Chacko T and Srivastava R K 2008 1891-1883 ma Southern Bastar-Cuddapah mafic igneous events, India: A newly recognized large igneous province; Precamb. Res. 160(3-4) 308-322.

Gopal Reddy T, Sarvothaman H and Vishawanatha Rao N 1992 Report on granite project, Mahabubnagar district, Andhra Pradesh; Unpubl. Rep. Geol. Surv. India, FS: 1988-90

Green D H 1971 Composition of basaltic magmas as indicators of conditions of origin: Application to oceanic volcanism; Phil. Trans. R. Soc. Lond. A 268 707-725.

Harish Kumar S B, Jayananda M, Kano T, Shadakshara Swamy N and Mahabaleswar B 2003 Late Archaean juvenile magmatism accretion process in the Eastern Dharwar craton; Kuppam-Karimangalam area; Geol Soc. India Memoir 50 375-408.

Helmy H M and El Mahallawi M M 2003 Gabbro Akarem mafic-ultramafic complex, Eastern Desert, Egypt: A late Precambrian analogue of Alaskan-type complexes; Mineral. Petrol. 77 85-108.

Helmy H M, Abd Yasser M, El-Rahman Y M, Yoshikawa M, Shibata T, Arai S, Tamura A and Kagami H 2014 Petrology and Sm-Nd dating of the Genina Gharbia Alaskan-type complex (Egypt): Insights into deep levels of Neoproterozoic island arcs; Lithos 198-199 263-280.

Herzberg C 2004 Geodynamic information in peridotite petrology; J. Petrol. 45(12) 2507-2530.

Himmelberg G R and Loney R A 1995 Characteristics and petrogenesis of Alaskantype ultramafic-mafic intrusions, Southeastern Alaska; US Geol. Surv. Prof. Paper 1564 $1-47$.

Irvine T N 1974 Petrology of the Duke island ultramafic complex, southern Alaska; Geol. Soc. Am. Memoir 138 240.

Jayananda M, Peucat J J, Chardon D, Krishna Rao B, Fanning C M and Corfu F 2013 Neoarchean greenstone volcanism and continental growth, Dharwar craton, southern India: Constraints from SIMS U-Pb zircon geochronology and Nd isotopes; Precamb. Res. 227 55-76.

Jayananda M, Santosh M and Aadhiseshan K R 2018 Formation of Archean (3600-2500 Ma) continental crust in the Dharwar craton, southern India; Earth Sci. Rev. 181 $12-42$.

Kamenetsky V S, Crawford A J and Meffre S 2001 Factors controlling chemistry of magmatic spinel: An empirical study of associated olivine, Cr-spinel and melt inclusions from primitive rocks; J. Petrol. 42 655-671.

Karmalkar N R, Duraiswami R A, Chalapathi Rao N V and Paul D K 2009 Mantle-derived mafic-ultramafic xenoliths and the nature of Indian sub-continental lithosphere; $J$. Geol. Soc. India 73(5) 657-679. 
Kutty T R N, Murthy S R N and Anantha Iyer G V 1986 REE geochemistry and petrogenesis of ultramafic rocks of Chalk Hills, Salem; J. Geol. Soc. India 28(6) 449-466.

La Flèche M R, Camiré G and Jenner G A 1998 Geochemistry of post-Acadian, Carboniferous continental intraplate basalts from the Maritimes Basin, Magdalen Islands, Quebéc, Canada; Chem. Geol. 148 115-136.

Leake B E et al. 1997 Nomenclature of amphiboles: report of the subcommitee on amphiboles of the international mineralogical association, commission on new minerals and mineral names; Am. Mineral. 82 1019-1037.

Le Bas M J, Subbarao K V and Walsh J N 2002 Metacarbonatite or marble? - The case of the carbonate, pyroxenite, calcite-apatite rock complex at Borra, Eastern Ghats, India; J. Asian Earth Sci. 20 127-140.

Loucks R 1990 Discrimination of ophiolitic from nonophiolitic ultramafic-mafic allochthons in orogenic belts by the $\mathrm{Al} / \mathrm{Ti}$ ratio in clinopyroxene; Geology 18 346-349.

Manikyamba C and Kerrich R 2012 Eastern dharwar craton, India: Continental lithosphere growth by accretion of diverse plume and arc terranes; Geosci. Front. 3 225-240.

Manu Prasanth M P, Hari K R, Chalapathi Rao N V, Hou G and Pandit D 2017 An island-arc tectonic setting for the Neoarchean Sonakhan Greenstone Belt, Bastar Craton, central India: Insights from the chromite mineral chemistry and geochemistry of the siliceous high-Mg basalts (SHMB); Geol. J., https://doi.org/10.1002/gj.2971.

McKenzie D P and O'Nions R K 1991 Partial melt distribution from inversion of rare earth element concentrations; J. Petrol. 32 1021-1109.

Meshram R and Venkateswara Rao S 2009 Mineralogy and geochemistry of lamprophyres from Kalwakurty, Mahabubnagar district, Andhra Pradesh; Ind. J. Geosci. 63(4) 361-372.

Middelburg J J, van der Weijden C H and Woittiez J R W 1988 Chemical processes affecting the mobility of major, minor and trace elements during weathering of granitic rocks; Chem. Geol. 68 253-273.

Miller C, Schuster R, Klötzli U, Frank W and Purtscheller F 1999 Post-collisional potassic and ultrapotassic magmatism in SW Tibet: Geochemical and Sr-Nd-Pb-O isotopic constraints for mantle source characteristics and petrogenesis; J. Petrol. 40 1399-1424.

Mishra D C and Prajapati S K 2003 A plausible model for evolution of schist belts and granite plutons of Dharwar craton, India and Madagascar during 3.0-2.5 Ga: Insight from gravity modeling constrained in part from seismic studies; Gondwana Res. 6 501-511.

Mondal S K, Ripley E M, Li C and Frei R 2006 The genesis of Archaean chromitites from the Nuasahi and Sukinda massifs in the Singhbhum craton, India; Precamb. Res. 148 45-66.

Morimoto N, Fabries J, Fergusen A K, Ginzburg I V, Ross M, Seifert F A, Zussman J, Aoki K and Gottardi G 1988 Nomenclature of pyroxenes; Am. Mineral. 73 1123-1133.

Morten L 1978 REE abundance in spinel-lherzolite nodules and host basalts; Mineral. Petrogr. Acta 17 15-40.

Mukherjee R, Mondal S K, Rosing M T and Frei R 2010 Compositional variations in the Mesoarchean chromites of the Nuggihalli schist belt, western Dharwar craton (India): Potential parental melts and implications for tectonic setting; Contrib. Mineral. Petrol. 160 865-885.
Naqvi S M and Rogers J W 1987 Precambrian Geology of India. viii 233 pp. New York, Oxford: Clarendon Press; Oxford University Press. ISBN 019503653 0. Geol. Mag. 125(5) 563-565.

Naqvi S M 2005 Geology and evolution of the Indian plate (from hadean to holocene - 4 Ga to $4 \mathrm{Ka}$ ); Capital Publishing Company, New Delhi, 450p.

Naqvi S M, Khan R M K, Manikyamba C, Ram Mohan M and Khanna T C 2006 Geochemistry of the Neoarchaean high-Mg basalts, boninites and adakites from the Kushtagi- Hungund greenstone belt of the Eastern Dharwar Craton (EDC): Implications for the tectonic setting; J. Asian Earth Sci. 27 25-44.

Natarajan M, Bhaskar Rao B, Parthasarathy R, Anil K and Gopalan K 19942.0 ga old pyroxenite-carbonatite complex of Hogenakal, Tamil Nadu, south India; Precamb. Res. 65 167-181.

Nelson D R 1989 Isotopic characteristics and petrogenesis of the lamproite and kimberlites of central west Greenland; Lithos 22 265-274.

Ottonello G, Piccardo G B, Mazzucetelli A and Cummino F 1978 Clinopyroxeneorthopyroxene major and rare earth elements partitioning in spinel peridotite xenoliths from Assab (Ethiopia); Geochim. Cosmochim. Acta $421817-$ 1828.

Pandey B K, Gupta J N, Sharma K J and Sastri C A 1997 $\mathrm{Sm}-\mathrm{Nd}, \mathrm{Pb}-\mathrm{Pb}$ and $\mathrm{Rb}-\mathrm{Sr}$ geochronology and petrogenesis of the mafic dyke swarm of Mahbubnagar, south India: Implications for Paleoproterozoic crustal evolution of the eastern Dharwar craton; Precamb. Res. 84 181-196.

Pandey A, Chalapathi Rao N V, Pandit D, Pankaj P, Pandey R, Sahoo S and Kumar A 2017a Subduction-tectonics in the evolution of the eastern Dharwar craton, southern India: Insights from the post-collisional calc-alkaline lamprophyres at the western margin of the Cuddapah basin; Precamb. Res. 298 235-251.

Pandey A, Chalapathi Rao N V, Chakrabarti R, Pandit D, Pankaj P, Kumar A and Sahoo S 2017b Petrogenesis of a Mesoproterozoic shoshonitic lamprophyre dyke from the Wajrakarur kimberlite field, southern India: Geochemical and Sr-Nd isotopic evidence for a modified sub-continental lithospheric mantle source; Lithos 292-293 218233.

Pearce J A 2008 Geochemical fingerprinting of oceanic basalts with applications to ophiolite classification and the search for Archean oceanic crust; Lithos 100 14-48.

Pearce J A and Cann J R 1973 Tectonic setting of basic volcanic rocks determined using trace element analysis; Earth Planet. Sci. Lett. 19 290-300.

Pearce J A, van der Laan S R, Arculus R J, Murton B J, Ishii T, Peate D W and Parkinson I J 1992 Boninite and harzburgite from Leg (Bonin-Mariana forearc): A case study of magma genesis during the initial stages of subduction; In: Proceedings of the ocean drilling program, scientific results, Vol. 125, Ocean Drilling Program, College Station, TX, pp. 623-659.

Pettigrew N T and Hattori K H 2006 The Quetico intrusions of western superior province: Neo-Archean examples of Alaskan/Ural-type mafic-ultramafic intrusions; Precamb. Res. 149 21-42.

Peucat J-J, Jayananda M, Chardon D, Capdevila R, Fanning Marc C and Paquette J-L 2013 The lower crust of 
Dharwar craton, south India: Patchwork of Archean granulitic domains; Precamb. Res. 227 4-29, https://doi.org/ 10.1016/j.precamres.2012.06.009.

Philpotts J A, Schnetzler C C and Thomas H H 1972 Petrogenetic implications of some: New geochemical data on eclogitic and ultrabasic inclusions; Geochim. Cosmochim. Acta 36 1131-1166.

Polat A and Hofmann A W 2003 Alteration and geochemical patterns in the 3.7-3.8 Ga Isua greenstone belt, West Greenland; Precamb. Res. 126 197-218.

Polat A and Kerrich R 2000 Archean greenstone belt volcanism and the continental growth-mantle evolution connection: Constraints from Th-U-Nb-LREE systematics of the $2.7 \mathrm{Ga}$ Wawa subprovince, Superior Province, Canada; Earth Planet. Sci. Lett. 175 41-54.

Radhakrishna B P and Naqvi S M 1986 Precambrian continental crust of India and its evolution; J. Geol. 94 145-166, https://doi.org/10.1086/629020

Rajesh H M 2003 Outcrop-scale silicate liquid immiscibility from and alkali syenite (A type granitoid) -pyroxenite association near Puttetti, Trivandrum block, south India; Contrib. Mineral. Petrol. 145 612-627.

Ramakrishnan M and Vaidyanadhan R 2008 Geology of India; Geol. Soc. India $\mathbf{5 5 6 .}$

Ram Mohan M, Piercey S J, Kamber B S and Sarma D S 2013 Subduction related tectonic evolution of the Neoarchean eastern Dharwar craton, southern India: New geochemical and isotopic constraints; Precamb. Res. 227 $204-226$

Rao A T and Raman C V 1979 Spinel bronzite pyroxenites from Vemparala, Andhra Pradesh; J. Geol. Soc. India 20 142-144.

Rao A D P, Rao K N and Murthy Y G K 1988 Gabbroanorthosite-pyroxenite complexes and alkaline rocks in Chimakurti-Elchuru area, Prakasam district, Andhra Pradesh; Rec. Geol. Surv. India 116 1-20.

Rock N M S 1991 Lamprophyres; Blackie, London, 225p.

Samuel V O, Kwon S, Santosh M and Sajeev K 2018 Garnet pyroxenite from Nilgiri Block, southern India: Vestiges of a Neoarchaen volcanic arc; Lithos 310-311 120-135.

Sappin A A, Constantin M and Clark T 2012 Petrology of mafic and ultramafic intrusions from the PortneufMauricie domain, Grenville Province, Canada: Implications for plutonic complexes in a proterozoic island arc; Lithos 154 277-295.

Shaw D M 1970 Trace element fractionation during anatexis; Geochim. Cosmochim. Acta 41 237-243.

Snoke A W, Quick J E and Bowman H R 1981 Bear mountain igneous complex, Klamath mountains, California: An ultrabasic to silicic calc-alkaline suite; J. Petrol. 22 501552.

Sobolev A V 2007 The amount of recycled crust in sources of mantle-derived melts; Science $\mathbf{3 1 6 ( 5 8 2 3 )}$ 412-417.

Srivastava R and Sinha A K 2007 Nd and Sr isotope systematics and geochemistry of a plume-related early cretaceous alkaline-mafic ultramafic igneous complex from Jasra, Shillong plateau, northeastern India; Geol. Soc. Am. 430 815-830, https://doi.org/10.1130/2007.2430(37).
Su B X, Qin K Z, Sakyi P A, Malaviarachchi S P K, Liu P P, Tang D M, Xiao Q H, Sun H, Ma Y G and Mao Q 2012 Occurrence of an Alaskan-type complex in the Middle Tianshan Massif, Central Asian Orogenic Belt: Inferences from petrological and mineralogical studies; Int. Geol. Rev. 54 249-269.

Su B X, Qin K Z, Zhou M F, Sakyi P A, Thakurta J, Tang D M, Liu P P, Xiao Q H and Sun H 2014 Petrological, geochemical and geochronological constraints on the origin of the Xiadong Ural-Alaskan type complex in NW China and tectonic implication for the evolution of southern Central Asian Orogenic Belt; Lithos 200-201 226-240.

Sun C M and Bertrad J 1991 Geochemistry of clinopyroxenes in plutonic and volcanic sequences from the Yanbian Proterozoic ophiolites (Sichuan Province, China): petrogenetic and geotectonic implications; Schweiz. Mineral. Petrog. Mitt. 71 243-259.

Sun S S and McDonough W F 1989 Chemical and isotopic systematics of oceanic basalts: Implications for mantle composition and processes. In: Magmatism in ocean basins (eds) Saunders A D and Norry M J, Geol. Soc. London, Spec. Publ. 42 313-345.

Swami Nath J, Ramakrishnan M and Viswanatha M N 1976 Dharwar stratigraphic model and Karnataka craton evolution; Rec. Geol. Surv. India 107 149-175.

Tainton K M and McKenzie D 1994 The generation of kimberlites, lamproites, and their source rocks; J. Petrol. 35 787-817.

Taylor H P Jr 1967 The zoned ultramafic complexes of southeastern Alaska, Part 4. III; In Ultramafic and related rocks (ed) Wyllie P J, New York, John Wiley 96-118.

Taylor S R and McLennan S M 1985 The continental crust: Its composition and evolution; Blackwell Scientific Publication, Carlton, 312p.

Tessalina S G, Kreshimir N, Malitch K N, Augé T, Puchkov V N, Belousova E and McInnes B A 2016 Origin of the Nizhny Tagil clinopyroxenite-dunite Massif, Uralian Platinum Belt, Russia: Insights from PGE and Os isotope systematic; J. Petrol. 56 2297-2318.

Tilhac R et al. 2017 Sources and timing of pyroxenite formation in the sub-arc mantle: Case study of the Cabo Ortegal Complex, Spain; Earth Planet. Sci. Lett., https://doi.org/ 10.1016/j.epsl.2017.07.017.

Velasco-Tapia F, Guevara M and Verma S P 2001 Evalution of concentration data in geochemical references materials; Chem. Erde - Geochem. 61(2) 69-91.

Weaver B L and Tarney J 1984 Empirical approach to estimating the composition of the continental crust; Nature 310 575-577.

Yuan L, Zhang X, Yang Z, Lu Y and Chen H 2017 Paleoproterozoic Alskan-type ultramafic-mafic intrusions in the Zhongtiao mountain region, North China craton: Petrogenesis and tectonic implication; Precamb. Res. 296 39-61.

Zhang C L, Yang D S, Wang H Y, Takahashi Y and Ye H M 2011 Neoproterozoic mafic-ultramafic layered intrusion in Quruqtagh of northeastern Tarim Block, NW China: Two phases of mafic igneous activity with different mantle sources; Gondwana Res. 19 177-190. 